\title{
Nutrient solution composition and growing season affect yield and chemical composition of Cichorium spinosum plants
}

\author{
Spyridon Petropoulos ${ }^{\mathrm{a}, *}$, Ângela Fernandes ${ }^{\mathrm{b}}$, Anestis Karkanis ${ }^{\mathrm{c}}$, Vasileios Antoniadis ${ }^{\mathrm{d}}$, \\ Lillian Barros ${ }^{\mathrm{b}}$, Isabel C.F.R. Ferreira ${ }^{\mathrm{b}, * *}$ \\ ${ }^{a}$ Laboratory of Vegetable Production, University of Thessaly, Fytokou Street, 38446 N. Ionia, Magnissia, Greece

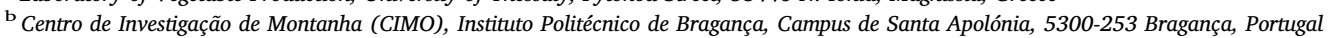 \\ ${ }^{\mathrm{c}}$ Laboratory of Weed Science, University of Thessaly, Fytokou Street, 38446 N. Ionia, Magnissia, Greece \\ ${ }^{\mathrm{d}}$ Laboratory of Soil Science, University of Thessaly, Fytokou Street, 38446 N. Ionia, Magnissia, Greece
}

\section{A R T I C L E I N F O}

\section{Keywords:}

Ammonium nitrogen

Antioxidant activity

Chemical composition

Chicoric acid

Fatty acids

Nitrates

Omega-3 fatty acids

Phenolic compounds

Total nitrogen

\begin{abstract}
A B S T R A C T
Nitrogen fertilizer form may affect quality and yield of leafy vegetables. In the present study, the effect of ammonium nitrogen rates on yield and chemical composition of Cichorium spinosum L. was examined. Five fertilizer treatments with different amounts of ammonium nitrogen (F1: 14\%, F2: 24\%, F3: 34\%, F4: 43\% and F5: $53 \% \mathrm{NH}_{4}-\mathrm{ON}$ of total $\mathrm{N}$ ) were applied. Fertilizer treatments had a significant effect on both plant fresh weight and chemical composition, depending on growing period and harvest stage. For both harvests of the 1st growing period, yield was higher in treatments $\mathrm{F} 4\left(43 \% \mathrm{NH}_{4}-\mathrm{N}\right)$ and $\mathrm{F} 5\left(53 \% \mathrm{NH}_{4}-\mathrm{N}\right)$, whereas in the 2nd growing period yield was higher for treatments F1, F2 and F3. Moreover, the highest content of total phenolics were recorded in the 2nd growing period. Antioxidant properties were also affected by fertilization treatments and growing periods, with antioxidant potency being higher in the 2nd growing period and for treatments F1 and F2. According to the results of the present study, nitrogen fertilizer form should be considered together with growing period and harvest stage as a useful means towards increasing the quality of the final product without compromising total yield.
\end{abstract}

\section{Introduction}

Cichorium spinosum $\mathrm{L}$. is a perennial species that forms a spiny shrub, more or less erect, depending on the ecotype. It is a basic ingredient of Mediterranean diet with people from rural communities usually hand picking the rosettes and use them in many traditional dishes (Melliou et al., 2003; Petropoulos et al., 2016). During the first year of growth, only one rosette of leaves is formed on each plant, while at the end of the first growth cycle a spiny flowering stem appears. The following years, more auxiliary buds are developed and many rosettes of leaves are formed.

The use of fertilizers has rapidly increased yield and farmers' income during the last decades; however the irrational use of nitrogen fertilizers has many negative implications for the environment and consumers' health, since excessive rates of nitrogen fertilizers can increase the risk of gastrointestinal cancer and methemoglobinemia (Hord et al., 2009). Moreover, nitrogen form may also affect the quality of the final product, since it is involved in the biosynthesis of various phytonutrients such as organic and fatty acids (Fontana et al., 2006;
Szalai et al., 2010). Conesa et al. (2009) have also reported that nitrate/ ammonium ratio in nutrient solution is essential for the yield and quality of baby leaf spinach and bladder campion plants, especially regarding oxalate content, which are considered anti-nutritional factors due to their association with kidney stone formation and deficiencies in calcium, copper, iron and magnesium (Zhang et al., 2005). According to Liu et al. (2015), the increase of ammonium nitrogen in nutrient solution did not increase oxalate content in spinach leaves, whereas oxalate accumulation is highly associated with nitrate nitrogen uptake. Furthermore, Zhang et al. (2005) suggested that a nitrate: ammonium nitrogen ratio of 0.5 can result in the lowest total oxalate in spinach leaves without compromising yield. Palaniswamy et al. (2004) have also reported that nitrate: ammonium nitrogen ratios may also affect the omega- 3 and total fatty acids content in purslane leaves, especially $\alpha$-linolenic acid which was higher at ratios of 0.5:0.5 of nitrate: ammonium nitrogen.

Apart from nutrient solution, growing period may also affect chemical composition and quality of leafy vegetables. According to Fallovo et al. (2009), the increase in nutrient solution concentration resulted in

\footnotetext{
* Corresponding author at: University of Thessaly, School of Agricultural Sciences, Fytokou Street, 38446, N. Ionia, Magnissia, Greece.

*** Corresponding author at: Polytechnic Institute of Bragança, Campus de Santa Apolónia, 1172, 5300-253 Bragança, Portugal.

E-mail addresses: fangio57gr@gmail.com (S. Petropoulos), iferreira@ipb.pt (I.C.F.R. Ferreira).
} 
an increase of biomass production and nitrate and chlorophyll content in lettuce plants, while growing plants during spring decreased yield and growth but increased quality in terms of carbohydrates and nitrates content, comparing to the summer growing period. Moreover, Bonasia et al. (2017) have reported seasonal differences in visual quality and nutritional profile of wild rocket, with colder periods (autumn-winter) resulting in better visual quality, whereas warmer periods (winterspring) were beneficial to nutritional profile in terms of nitrates, total phenols, ascorbic acid and glucosinolates content. According to Becker et al. (2014), light intensity and growth stage may affect phenolic compounds composition, such as cyanidin and quercetin glucosides in lettuce plants grown under shading nets, while Becker et al. (2013) reported that the reduction of flavonoid glycosides content under low light intensities is fully compensated when plants are subsequently subjected to high photosynthetic photon flux density. Moreover, other phenolic compounds such as caffeic acid derivatives were not affected by shading conditions (Becker et al., 2014), which indicates that apart from environmental factors, ontogeny is also important for chemical composition of leafy vegetables. Fu et al. (2017) and Stagnari et al. (2015) have also demonstrated the significance of light intensity on quality of leafy vegetables, especially regarding nitrates and vitamin C content which are crucial quality features for lettuce, while Petropoulos et al. (2017a) have highlighted the effect of growing period on C. spinosum nutritional value and chemical composition.

Although chemical composition and nutritional profile of C. spinosum has been already described (Petropoulos et al., 2016; Zeghichi et al., 2003), scarce literature regarding the effect of cultivation practices on these parameters is available so far. Therefore, the aim of the present study was to evaluate the effect of ammonium nitrogen rates on plant yield, and chemical composition and nutritional profile of $C$. spinosum leaves, especially on quality features such as phenolic compounds content and fatty acids composition.

\section{Materials and methods}

\subsection{Experimental design, plant material and growing conditions}

Plants were grown in an unheated plastic greenhouse at the experimental farm of the University of Thessaly in Velestino, Greece (Latitude: $39^{\circ} 38^{\prime} 86^{\prime \prime} \mathrm{N}$; Longitude: $22^{\circ} 94^{\prime} 14^{\prime \prime} \mathrm{E}$ ). More specifically, seeds collected from Crete island (Greece) were sown in seed trays on September 2nd 2015 and December 15th 2015 (growing period 1 and 2, respectively) containing peat by Vianame S.A. (Timpaki, Greece) (Anesti et al., 2016). Seedlings of Cichorium spinosum L. (Vianame S.A.; Timpaki, Greece) were transplanted at the stage of 3 true leaves in $2 \mathrm{~L}$ pots containing peat (Klassman-Deilmann KTS2, 1.0 L) and perlite $(1.0 \mathrm{~L})$.

The experiment was set up as a factorial with three factors [1st Factor: growing period with two levels (G1: transplanting on December 5th, 2015, G2: transplanting February 15th, 2016); 2nd factor: number of harvests with three levels (H1: 1st harvest, H2: 2nd harvest, H3: one harvest at the same day of 2nd harvest with no previous cutting); 3rd Factor: fertilization treatments (F1: $14 \% \mathrm{NH}_{4}-\mathrm{N}, \mathrm{F} 2: 24 \% \mathrm{NH}_{4}-\mathrm{N}, \mathrm{F} 3$ : $34 \% \mathrm{NH}_{4}-\mathrm{N}, \mathrm{F} 4: 43 \% \mathrm{NH}_{4}-\mathrm{N}, \mathrm{F} 5: 53 \% \mathrm{NH}_{4}-\mathrm{N}$ of total nitrogen)], and laid out in a Completely Randomized design with 10 pots per treatment $(\mathrm{n}=10)$.

Regarding the fertilization treatments, plants were fertilized with the same amount of nitrogen, phosphorus and potassium through the nutrient solution, twice a week at the start of the experiment $(50 \mathrm{~mL}$ per pot) and after transplantation of seedlings and thrice a week at later growth stages and when temperatures increased $(300 \mathrm{~mL}$ per pot). Nutrient solution for each fertilization treatment (Table 1) was composed to simulate commercial growing conditions in terms of total nitrogen amount, while $\mathrm{pH}$ was adjusted at 6.5 for all treatments. Therefore only commercial fertilizers were used as previously described by Anesti et al. (2016), namely: a) 20-20-20 (N-P-K) with nitrogen
Table 1

Nutrient solution composition expressed in \% of nitrogen.

\begin{tabular}{|c|c|c|c|c|c|}
\hline \multirow[t]{2}{*}{ Elements } & \multicolumn{5}{|c|}{ Treatments } \\
\hline & 1 & 2 & 3 & 4 & 5 \\
\hline Total N (ppm) & 299.95 & 300.13 & 300.40 & 300.01 & 299.97 \\
\hline NO3-N & 36.3 & 46.3 & 49.5 & 43.7 & 37.0 \\
\hline NH4-N & 13.7 & 23.7 & 33.7 & 43.0 & 53.0 \\
\hline Urea & 50.0 & 30.0 & 16.8 & 13.3 & 10.0 \\
\hline
\end{tabular}

consisting of urea (10\%), $\mathrm{NO}_{3}-\mathrm{N}(5.6 \%)$ and $\mathrm{NH}_{4}-\mathrm{N}(4.4 \%)$, b) ammonium nitrate $\left(34.5 \%\right.$ total nitrogen, with a ratio of $1: 1$ for $\mathrm{NO}_{3}-\mathrm{N}: \mathrm{NH}_{4}-$ $\mathrm{N})$, c) calcium nitrate (15.5\% nitrogen, $\left[\mathrm{NO}_{3}-\mathrm{N}(14.4 \%)\right.$ and $\mathrm{NH}_{4}-\mathrm{N}$ (1.1\%)], and $26.5 \% \mathrm{CaO}), \mathrm{d})$ urea (46\% nitrogen in urea form), e) ammonium sulphate $\left(21 \%\right.$ of nitrogen in $\mathrm{NH}_{4}-\mathrm{N}$ form, and $24 \%$ sulfur. Concerning the harvest treatments, for the 1st growing period and $\mathrm{H} 1$ and $\mathrm{H} 2$ treatments, the harvest was carried out at $82(25 / 02 / 2016)$ and 118 days (01/04/2016) after transplantation (DAT), respectively, while for $\mathrm{H} 3$ treatment, harvest took place at the same day as the second harvest (118 DAT; 01/04/2016). For growing period 2, only one harvest (H1 treatment) took place at 78 DAT (03/05/2016), since climate conditions induced early flowering. After harvest fresh and dry weight of leaves was recorded, while samples of raw leaves were stored at $-80^{\circ} \mathrm{C}$ and lyophilized for further analyses. Climate conditions during the experimental period are presented in Fig. 1. Data for temperatures inside the greenhouse were obtained from Onset HOBO RH/Temp data logger (Onset Computer Corporation, MA, USA), while solar radiation data were obtained from the meteorological station of the University of Thessaly, located near the experimental site.

\subsection{Standards and reagents}

Acetonitrile (99.9\%) was of HPLC grade (Fisher Scientific, Portugal). Formic acid was purchased from Panreac Química S.L.U. (Barcelona, Spain). L-ascorbic acid, fatty acid methyl esters reference standard (standard 47885-U), fatty acids isomers, organic acids, sugars and tocopherol standards were purchased by Sigma-Aldrich Quimica S.L. (Madrid, Spain). Phenolic standards were from Extrasynthèse (Genay, France). Water was treated in a Milli-Q water purification system (TGI Pure Water Systems, USA).

\subsection{Chemical composition analyses}

Free sugars and tocopherols were determined following procedures previously described by Guimarães et al. (2013). Free sugars analysis was performed by high performance liquid chromatography with a refraction index detector (HPLC-RI; Knauer, Smartline system 1000, Germany). Chromatographic separation was achieved using a Eurospher 100-5 NH2 column $(4.6 \times 250 \mathrm{~mm}, 5 \mathrm{~mm}$, Knauer $)$, operating at $35{ }^{\circ} \mathrm{C}$ (7971 R Grace oven). Elution was performed with acetonitrile/ water, $70: 30(\mathrm{v} / \mathrm{v})$ at a flow rate of $1 \mathrm{~mL} / \mathrm{min}$ and controlled by Clarity 2.4 Software (DataApex, Czech Republic). Sugars were identified by comparing their retention times with standard compounds and quantification was conducted by comparison with dose-response curves constructed from authentic standards, using the internal standard (IS, melezitose) method.

Chromatographic separation of tocopherols was achieved using an HPLC equipment, with a fluorescence detector (FP-2020; Jasco, USA), programmed for excitation at $290 \mathrm{~nm}$ and emission at $330 \mathrm{~nm}$. The compounds were identified by chromatographic comparisons with authentic standards. Tocopherols were identified by comparing their retention times with standard compounds and quantification was conducted by comparison with dose-response curves constructed from authentic standards, using the IS (tocol) method.

Organic acids were determined following a procedure previously 


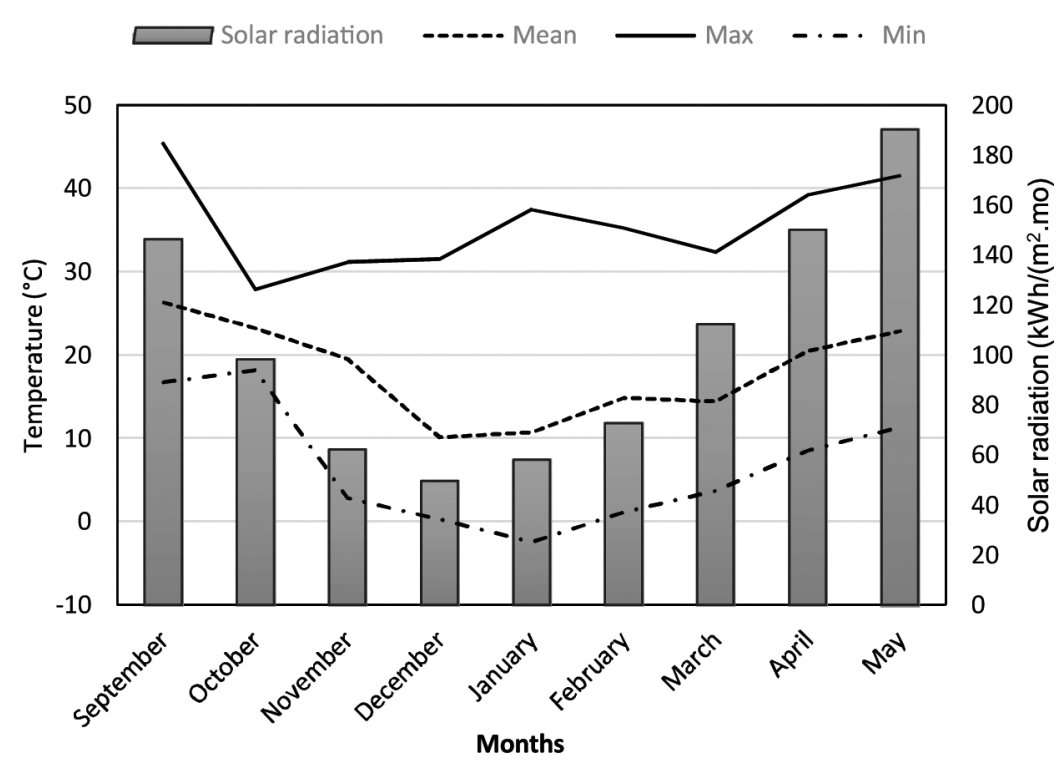

Fig. 1. Mean, max and min temperature $\left({ }^{\circ} \mathrm{C}\right)$, and solar radiation kWh/ $\left(\mathrm{m}^{2} \mathrm{mo}\right)$ during the growing season (September 2015-May 2016). described by Pereira et al. (2013). Analysis was performed using a Shimadzu 20A series UFLC (Shimadzu Coperation, Japan). Separation was achieved on a SphereClone (Phenomenex, USA) reverse phase $\mathrm{C}_{18}$ column $\left(5 \mu \mathrm{m}, 250 \mathrm{~mm} \times 4.6 \mathrm{~mm}\right.$ i.d), operating at $35^{\circ} \mathrm{C}$. Elution was performed with sulphuric acid $3.6 \mathrm{mM}$ using a flow rate of $0.8 \mathrm{~mL} / \mathrm{min}$. Detection was carried out in a DAD, using $215 \mathrm{~nm}$ and $245 \mathrm{~nm}$ (for ascorbic acid) as preferred wavelengths and controlled by LabSolutions multi LC-DAD software (Shimadzu Coperation, Japan). Organic acids were quantified by comparison of their peaks area recorded at 215 or $245 \mathrm{~nm}$ with calibration curves obtained from commercial standards.

Fatty acids were analysed with a DANI 1000 gas chromatographer (GC, Italy) coupled to a flame ionization detector (FID), after a transesterification procedure (Guimarães et al., 2013). FAMEs were identified by comparing their retention time with authentic standards and the results were recorded and processed using Clarity 4.0.1.7 Software (DataApex, Czech Republic).

$\mathrm{Ca}, \mathrm{Mg}, \mathrm{Fe}, \mathrm{Mn}, \mathrm{Zn}$, and $\mathrm{Cu}$ content was determined by atomic absorption spectrophotometry (Perkin Elmer 1100B, USA) and K content by flame photometry (Sherwood Model 410, UK; Petropoulos et al., 2015)

Total nitrogen in leaves was measured according to Kjeldahl method (O'Bryan et al., 2017). Briefly, total nitrogen was determined as follows: $1 \mathrm{~g}$ of tissue was digested in glass tubes at $450^{\circ} \mathrm{C}$ for $4 \mathrm{~h}$ with concentrated $\mathrm{H}_{2} \mathrm{SO}_{4}$ until samples were transparent. Then the contained $\mathrm{NH}_{4}-\mathrm{N}$ in the digestion tubes was distilled in the presence of $40 \%$ alkali as $\mathrm{NaOH}$ for the production of $\mathrm{NH}_{3}$, which was subsequently titrated with $0.1 \mathrm{~N}$ acid $\left(\mathrm{H}_{2} \mathrm{SO}_{4}\right)$ until neutralization. Nitrate content was assessed colorimetrically by the nitration of salicylic acid, following the procedure previously described by Cataldo et al. (1975), using a Perkin Elmer Model Lambda 1A spectrophotometer (Perkin Elmer, Waltham, Mass.).

\subsection{Antioxidant activity assays}

One gram of lyophilized material was extracted twice for $1 \mathrm{~h}$ in a magnetic stirrer plate $\left(25^{\circ} \mathrm{C}\right.$ at $\left.150 \mathrm{rpm}\right)$, with $30 \mathrm{~mL}$ of methanol/ water $(80: 20, v / v)$, filtered through a Whatman No. 4 paper and vacuum-dried in a rotary evaporator (Büchi R-210, Switzerland) at $40{ }^{\circ} \mathrm{C}$ to remove the methanol. The extracts were further frozen and lyophilized, re-dissolved in methanol/water $(80: 20, v / v)$ for in vitro antioxidant activity assays at a final concentration of $20 \mathrm{mg} / \mathrm{mL}$, and further diluted to different concentrations.

DPPH radical-scavenging activity was evaluated with an ELX800 microplate reader (Bio-Tek Instruments, Inc., USA), and calculated as a percentage of DPPH discolouration using the formula: $\left[\left(\mathrm{A}_{\mathrm{DPPH}^{-}}-\mathrm{A}_{\mathrm{S}}\right)\right.$ / $\left.A_{D P P H}\right] \times 100$, where $A_{S}$ is the absorbance of sample solution at $515 \mathrm{~nm}$, and $A_{D P P H}$ is the absorbance of the DPPH solution. Reducing power was evaluated by the capacity to convert $\mathrm{Fe}^{3+}$ to $\mathrm{Fe}^{2+}$, measuring the absorbance at $690 \mathrm{~nm}$ in the abovementioned microplate reader. Inhibition of $\beta$-carotene bleaching was evaluated though the $\beta$ carotene/linoleate assay; the neutralization of linoleate free radicals avoids $\beta$-carotene bleaching, which is measured by the formula: $\beta$ carotene absorbance after $2 \mathrm{~h}$ of assay/initial absorbance) $\times 100$. Lipid peroxidation inhibition in porcine brain homogenates was evaluated by the decrease in thiobarbituric acid reactive substances (TBARS); the color intensity of the malondialdehyde-thiobarbituric acid (MDA-TBA) was measured by its absorbance at $532 \mathrm{~nm}$; the inhibition ratio (\%) was calculated using the following formula: $[(\mathrm{A}-\mathrm{B}) / \mathrm{A}] \times 100 \%$, where $\mathrm{A}$ and $B$ were the absorbance of the control and the sample solution, respectively (Petropoulos et al., 2015). The results were expressed in $\mathrm{EC}_{50}$ values (sample concentration providing $50 \%$ of antioxidant activity for $\mathrm{DPPH}, \beta$-carotene bleaching and TBARS assays, or 0.5 of absorbance at $690 \mathrm{~nm}$ for the reducing power assay) for antioxidant activity and Trolox was used as a positive control.

\subsection{Phenolic compounds analysis}

The above-mentioned extracts were re-dissolved in methanol/water $(80: 20, v / v)$ at a final concentration of $15 \mathrm{mg} / \mathrm{mL}$ and filtered through a $0.45 \mu \mathrm{m}$ Whatman syringe filter, transferred to amber color HPLC vial for phenolic compound analysis.

The phenolic profile was determined by LC-DAD-ESI/MSn (Dionex Ultimate 3000 UPLC, Thermo Scientific, USA; Bessada et al., 2016). For double online detection, 280, 330 and $370 \mathrm{~nm}$ were used as preferred wavelengths for DAD and in a mass spectrometer (MS) connected to HPLC system. The MS detection was performed in negative mode, using a Linear Ion Trap LTQ XL mass spectrometer (ThermoFinnigan, USA) equipped with an ESI source. Phenolic compounds identification was performed using standard compounds when available, by comparison with their retention times, UV-vis and mass spectra, and by comparing the obtained information with available data reported in the literature giving a tentative identification. For quantitative analysis, a calibration curve for each available phenolic standard was constructed based on the UV signal. When commercial standards were not available, the quantification was performed through the calibration curve of the most similar available standard. The results were expressed as $\mathrm{mg} / \mathrm{g}$ of extract. 


\subsection{Statistical analyses}

The results are expressed as mean values and standard deviations (SD), and analysed using multifactor analysis of variance (ANOVA) for the main effects, followed by Tukey's HSD Test $(p=0.05)$ for means comparison. However, due to early anthesis of plants during the 2nd growing period only one harvest was carried out and G x H x F and G x $\mathrm{H}$ interactions could not be analysed. Therefore comparison of the data regarding both growing seasons were analysed as a two-factor factorial experiment ( $\mathrm{G} \times \mathrm{F}$ ), since $\mathrm{H}$ factor was not complete for both growing seasons. For 1st and 2nd growing season the $\mathrm{H} \mathrm{x} \mathrm{F}$ interaction of mean effects was also analysed. For chemical composition analyses, three samples were analysed for each treatment, while all the assays were carried out in triplicate. Statistical analysis was carried out with Statgraphics 5.1.plus (Statpoint Technologies, Inc., VA, USA).

\section{Results and discussion}

Ammonium fertilizer rates had a significant effect on plant growth and quality features of $C$. spinosum leaves. In particular, fresh weight for both harvests of the 1st growing period, as well as total fresh weight for $\mathrm{H} 3$ treatment, was higher in treatments F4 and F5, indicating that the nitrogen availability in the growth medium is essential for higher yields during winter and early spring where 1st growing period took place where low temperatures occurred (Table 2; Fig. 1). In addition, total fresh weight was higher when plants were harvested twice comparing to plants that were harvested only once for all the fertilizer treatments, whereas fresh weight for second harvest was significantly lower than that of the first harvest. Similar results have been reported by the authors (Petropoulos et al., 2017b) who evaluated the effect of successive harvesting on yield and chemical composition of C. spinosum leaves. Higher contents of ammonium nitrogen in the nutrient solution (treatments F4 and F5) had no beneficial effect in terms of fresh weight during the 2nd growing period, probably due to higher growth rates of plants during this period and the shorter growth cycles due to early anthesis, comparing to the 1st growing condition. It could be assumed that during winter growing period, the higher yield for treatments with high content of ammonium nitrogen in nutrient solution (F4 and F5), as well as for the late harvest (H3) could be attributed to different ammonium uptake rates in the growth medium as well as to environmental variables (e.g. temperature, $\mathrm{pH}$, nutrient supply) that may affect plant growth responses to various nitrogen sources (Britto and Kronzucker, 2013). In addition, Bloom et al. (1989) have suggested that although nitrates assimilation has no effect on carbon fixation and plant growth under high light environments, it may result in stunted plant growth under limited light conditions due to decreased mitochondrial electron transport. Recently, Chatzigianni et al. (2017) have reported that $C$. spinosum showed no differential response to increasing amounts of ammonium nitrogen in nutrient solution $(0.05-0.5$ of total nitrogen in nutrient solution), which indicates a tolerance of the species in high amounts of ammonium. Therefore, the results of our study could be further explained by: (i) the lower temperatures during the winter, since according to Kim et al. (2006) temperatures below $10^{\circ} \mathrm{C}$ inhibit nitrification significantly, (ii) the effect of nitrogen form on water uptake and consumption, since according to Guo et al. (2002) a higher water uptake and lower water consumption was observed in Phaseolus vulgaris plants that received solely nitrate nitrogen or spatially separated supply of ammonium and nitrate nitrogen comparing to plants that received only ammonium nitrogen, (iii) to plant species preference to specific nitrogen source e.g. nitrate and ammonium specialists (Bose and Srivasava, 2001; Britto and Kronzucker, 2013; Glass et al., 2002). Although treatments F3 and F4 contained higher amounts of ammonium nitrogen, the relative ratios of nitrate: ammonium were 1.02 and 0.7, respectively (Table 1). According to Marschner (1995) higher growth rates are reported when both forms of $\mathrm{N}$ are supplied, since plant regulate easier intracellular $\mathrm{pH}$ and are able to store $\mathrm{N}$ at lower
Table 2

Fresh (g/plant) and dry weight (\%) of Cichorium spinosum leaves in relation to nitrogen fertilization (F), number of harvests $(\mathrm{H})$ and growing period $(\mathrm{G})$.

\begin{tabular}{|c|c|c|c|c|c|}
\hline \multicolumn{6}{|c|}{ Fresh weight of leaves (g/plant) } \\
\hline \multirow[t]{4}{*}{ Fertilization (F) } & \multicolumn{5}{|c|}{ Growing period } \\
\hline & G1 & & & & G2 \\
\hline & \multicolumn{5}{|l|}{ Harvest } \\
\hline & $\mathrm{H} 1$ & $\mathrm{H} 2$ & H3 & $\begin{array}{l}\text { Total fresh } \\
\text { weight }=\mathrm{H} 1+\mathrm{H} 2\end{array}$ & $\mathrm{H} 1$ \\
\hline $\mathrm{F} 1$ & $29.3^{\mathrm{bcA}}$ & $21.4^{\mathrm{bcB}}$ & $39.5^{\mathrm{abB}}$ & $50.7^{\mathrm{bA}}$ & $19.6^{\mathrm{a} *}$ \\
\hline F2 & $25.4^{\mathrm{cA}}$ & $16.4^{\mathrm{dB}}$ & $29.0^{\mathrm{bB}}$ & $41.8^{\mathrm{bA}}$ & $20.4^{\mathrm{a} *}$ \\
\hline F3 & $31.8^{\mathrm{bcA}}$ & $18.0^{\mathrm{cdB}}$ & $34.3^{\mathrm{abB}}$ & $49.8^{\mathrm{bA}}$ & $20.2^{\mathrm{a} *}$ \\
\hline F4 & $41.7^{\mathrm{aA}}$ & $24.0^{\mathrm{abB}}$ & $44.0^{\mathrm{aB}}$ & $65.6^{\mathrm{aA}}$ & $14.9^{\mathrm{b}}$ \\
\hline F5 & $35.5^{\mathrm{abA}}$ & $27.2^{\mathrm{aB}}$ & $30.0^{\mathrm{bB}}$ & $62.7^{\mathrm{aA}}$ & $15.2^{\mathrm{b} ;}$ \\
\hline Standard error & 2.8 & 2.0 & 2.8 & 4.4 & 1.2 \\
\hline
\end{tabular}

Dry weight of leaves (\%)

\begin{tabular}{|c|c|c|c|c|c|}
\hline \multirow[t]{4}{*}{ Fertilization (F) } & \multicolumn{5}{|c|}{ Growing period } \\
\hline & \multicolumn{4}{|l|}{ G1 } & \multirow[t]{2}{*}{ G2 } \\
\hline & \multicolumn{4}{|c|}{ Harvest } & \\
\hline & $\mathrm{H} 1$ & $\mathrm{H} 2$ & H3 & $\begin{array}{l}\text { Total dry } \\
\text { weight }=\mathrm{H} 1+\mathrm{H} 2\end{array}$ & $\mathrm{H} 1$ \\
\hline $\mathrm{F} 1$ & $9.4^{\mathrm{aA}}$ & $8.8^{\mathrm{bA}}$ & $10.9^{\mathrm{bA}}$ & $8.8^{\mathrm{bB}}$ & $11.7^{\mathrm{c} *}$ \\
\hline F2 & $9.5^{\mathrm{aA}}$ & $10.2^{\mathrm{aA}}$ & $11.1^{\mathrm{abA}}$ & $10.2^{\mathrm{aB}}$ & $13.7^{\mathrm{a} *}$ \\
\hline F3 & $8.5^{\mathrm{aB}}$ & $10.1^{\mathrm{aA}}$ & $11.9^{\mathrm{aA}}$ & $10.1^{\mathrm{aB}}$ & $12.2^{\mathrm{bc} *}$ \\
\hline F4 & $8.4^{\mathrm{aA}}$ & $9.5^{\mathrm{abA}}$ & $10.6^{\mathrm{bA}}$ & $9.5^{\mathrm{abA}}$ & $12.6^{\mathrm{b} *}$ \\
\hline F5 & $8.7^{\mathrm{aB}}$ & $10.2^{\mathrm{aA}}$ & $11.9^{\mathrm{aA}}$ & $10.1^{\mathrm{aB}}$ & $12.4^{\mathrm{bc} *}$ \\
\hline Standard error & 0.2 & 0.3 & 0.3 & 0.3 & 0.3 \\
\hline
\end{tabular}

*G: Growing period treatments (G1: 1st growing period, G2: 2nd growing period); H: Harvest treatments (H1: 1 st harvest, H2: 2nd harvest, H3: one harvest at the same day of 2nd harvest with no previous cutting); F: Fertilization treatments (F1: 14\% NH4-N, F2: 24\% NH4-N, F3: 34\% NH4-N, F4: 43\% NH4N, F5: 53\% NH4-N); Means in columns followed by different small letters, and means in rows followed by different capital letters (for comparisons of $\mathrm{H} 1$ and $\mathrm{H} 2$ and $\mathrm{H} 3$ and $\mathrm{H} 1+\mathrm{H} 2$ pairs, accordingly) are significantly different by Tukey HSD test at $\mathrm{p}<.05$. Differences between the growing seasons (G1 and G2) for the same fertilization treatment are indicated by the use of $\left(^{*}\right)$ symbol.

energy costs. In the 2nd growing period, fresh weight was lower in all the fertilizer treatments compared to that of the 1st growing period, mostly due to early flower induction that hindered leaves formation (Table 2).

Similar results have been reported for other leafy vegetables, with multiple harvests increasing significantly total yield comparing to a single harvest (Csizinszky, 1999; Kmiecik and Lisiewska, 1999). This could be attributed to the fact that leafy vegetables which form rosettes are able to resume vegetative growth after harvest, as long as the apex is not destroyed. In contrast, according to Szalai et al. (2010) and (Fontana et al., 2006) high ammonium nitrogen rates reduced fresh weight of purslane plants (Portulaca oleracea L.), which could be due to the shorter growth cycle of purslane comparing to C. spinosum plants, as well as to preference in nitrate over ammonium nitrogen (Britto and Kronzucker, 2013). Although nitrates uptake from plants requires a higher amount of fixed carbon comparing to ammonium nitrogen, there are species that prefer nitrates over ammonium, since the easier entry of the latter into roots can result in considerable ammonium accumulation and consequent toxic effects and antagonism with other cationic nutrients such as $\mathrm{K}, \mathrm{Mg}$ and Ca (Britto and Kronzucker, 2002). Moreover, according to Marschner (1995) and Britto and Kronzucker (2002) the negative effects of ammonium nitrogen have been associated with changes of $\mathrm{pH}$ of growth medium and the toxicity of free $\mathrm{NH}_{4}{ }^{+}$. Considering that in our study no negative effects of ammonium nitrogen 
Table 3

Composition in main sugars ( $\mathrm{g} / \mathrm{kg}$ fresh weight) of Cichorium spinosum leaves (mean $\pm \mathrm{SD}$ ) in relation to nitrogen fertilization, number of harvests and growing period.

\begin{tabular}{|c|c|c|c|c|c|c|}
\hline \multicolumn{7}{|c|}{ Sugars (g/kg fw) } \\
\hline Harvest & Fertilization & Fructose & Glucose & Sucrose & Trehalose & Total Sugars \\
\hline \multicolumn{7}{|c|}{ 1st Growing period } \\
\hline \multirow[t]{5}{*}{ H1 } & $\mathrm{F} 1$ & $0.90^{\mathrm{eB}}$ & $2.73^{\mathrm{cB}}$ & $2.72^{\mathrm{bB}}$ & $0.72^{\mathrm{bcC}}$ & $7.06^{\mathrm{dB}}$ \\
\hline & $\mathrm{F} 2$ & $1.33^{\mathrm{cA}}$ & $3.51^{\mathrm{bA}}$ & $4.77^{\mathrm{aA}}$ & $0.32^{\mathrm{dB}}$ & $9.93^{\mathrm{aA}}$ \\
\hline & F3 & $1.44^{\mathrm{bC}}$ & $4.23^{\mathrm{aB}}$ & $1.12^{\mathrm{dC}}$ & $0.93^{\mathrm{aB}}$ & $7.70^{\mathrm{cC}}$ \\
\hline & F4 & $1.96^{\mathrm{aC}}$ & $4.37^{\mathrm{aB}}$ & $1.98^{\mathrm{ceC}}$ & $0.73^{\mathrm{bB}}$ & $9.00^{\mathrm{bB}}$ \\
\hline & F5 & $1.17^{\mathrm{dC}}$ & $2.57^{\mathrm{dB}}$ & $1.30^{\mathrm{dC}}$ & $0.52^{\mathrm{cC}}$ & $5.56^{\mathrm{eC}}$ \\
\hline \multirow[t]{5}{*}{$\mathrm{H} 2$} & $\mathrm{~F} 1$ & $0.65^{\mathrm{eC}}$ & $1.35^{\mathrm{eC}}$ & $0.95^{\mathrm{dC}}$ & $0.80^{\mathrm{cB}}$ & $3.76^{\mathrm{eC}}$ \\
\hline & $\mathrm{F} 2$ & $0.80^{\mathrm{cC}}$ & $2.83^{\mathrm{cC}}$ & $4.15^{\mathrm{aC}}$ & $0.59^{\mathrm{dA}}$ & $8.40^{\mathrm{bC}}$ \\
\hline & F3 & $1.73^{\mathrm{aB}}$ & $3.07^{\mathrm{aC}}$ & $3.03^{\mathrm{bB}}$ & $1.36^{\mathrm{aB}}$ & $9.20^{\mathrm{aB}}$ \\
\hline & $\mathrm{F} 4$ & $0.73^{\mathrm{dC}}$ & $2.927^{\mathrm{bC}}$ & $2.37^{\mathrm{cB}}$ & $0.76^{\mathrm{cA}}$ & $6.79^{\mathrm{dC}}$ \\
\hline & F5 & $1.22^{\mathrm{bB}}$ & $2.24^{\mathrm{dC}}$ & $2.92^{\mathrm{bA}}$ & $0.85^{\mathrm{bA}}$ & $7.25^{\mathrm{cB}}$ \\
\hline \multirow[t]{5}{*}{ H3 } & $\mathrm{F} 1$ & $1.62^{\mathrm{dA}}$ & $3.24^{\mathrm{dA}}$ & $3.11^{\mathrm{dA}}$ & $1.23^{\mathrm{bA}}$ & $9.20^{\mathrm{dA}}$ \\
\hline & $\mathrm{F} 2$ & $0.86^{\mathrm{eA}}$ & $2.96^{\mathrm{eB}}$ & $4.33^{\mathrm{bB}}$ & $0.65^{\mathrm{dA}}$ & $8.80^{\mathrm{eB}}$ \\
\hline & F3 & $1.95^{\mathrm{bA}}$ & $6.31^{\mathrm{aA}}$ & $4.10^{\mathrm{cA}}$ & $1.93^{\mathrm{aA}}$ & $14.30^{\mathrm{aA}}$ \\
\hline & F4 & $2.43^{\mathrm{aA}}$ & $5.58^{\mathrm{bA}}$ & $3.04^{\mathrm{eA}}$ & $0.72^{\mathrm{cB}}$ & $11.80^{\mathrm{cA}}$ \\
\hline & F5 & $1.76^{\mathrm{cA}}$ & $5.33^{\mathrm{cA}}$ & $4.39^{\mathrm{aA}}$ & $0.73^{\mathrm{cB}}$ & $12.21^{\mathrm{bA}}$ \\
\hline \multicolumn{7}{|c|}{ 2nd Growing period } \\
\hline \multirow[t]{5}{*}{ H1 } & F1 & $0.61^{\mathrm{c} *}$ & $1.40^{\mathrm{d} *}$ & $3.50^{\mathrm{d} *}$ & $0.99^{\mathrm{a} *}$ & $6.50^{\mathrm{e} *}$ \\
\hline & $\mathrm{F} 2$ & $0.57^{\mathrm{c}_{*}}$ & $2.95^{\mathrm{a} *}$ & $5.81^{\mathrm{a} *}$ & $0.60^{\mathrm{c} *}$ & $9.92^{\mathrm{a}}$ \\
\hline & F3 & $0.75^{\mathrm{b} *}$ & $2.14^{\mathrm{b} *}$ & $4.82^{\mathrm{c} *}$ & $0.64^{\mathrm{c} *}$ & $8.35^{\mathrm{c} *}$ \\
\hline & F4 & $0.75^{\mathrm{b} *}$ & $1.87^{\mathrm{c} *}$ & $5.52^{\mathrm{b} *}$ & $0.99^{\mathrm{a} *}$ & $9.13^{\mathrm{b}}$ \\
\hline & F5 & $0.90^{\mathrm{a} *}$ & $1.35^{\mathrm{d} *}$ & $4.85^{\mathrm{c} *}$ & $0.83^{\mathrm{b} *}$ & $7.94^{\mathrm{d}_{*}}$ \\
\hline \multicolumn{2}{|c|}{ Standard error } & 0.12 & 0.31 & 0.32 & 0.08 & 0.53 \\
\hline
\end{tabular}

*H: Harvest treatments (H1: 1st harvest, $\mathrm{H} 2$ : 2nd harvest, $\mathrm{H} 3$ : one harvest at the same day of 2nd harvest with no previous cutting); F: Fertilization treatments (F1: $14 \% \mathrm{NH}_{4}-\mathrm{N}, \mathrm{F} 2$ : 24\% $\mathrm{NH}_{4}-\mathrm{N}$, F3: $34 \% \mathrm{NH}_{4}-\mathrm{N}$, F4: $43 \% \mathrm{NH}_{4}-\mathrm{N}$, F5: $53 \% \mathrm{NH}_{4}-\mathrm{N}$ ); For each growing period, small letters refer to comparison between means of fertilization treatments for the same harvest stage; capital letters refer to comparisons between means of the same fertilization treatment for the 1st growing period, regardless of harvest stage; differences between the growing seasons for $\mathrm{H} 1$ treatment and the same fertilization treatment are indicated by the use of $(*)$ symbol. Mean separation was made with Tukey HSD test at $\mathrm{p}<.05$. were observed in the early growth stages (1st harvest), it could indicate a cumulative effect of $\mathrm{NH}_{4}{ }^{+}$on growth media which occurred only at late growth stages and after the application of significant amounts of nutrient solution.

Dry weight in the 1 st growing period did not differ significantly in the 1st harvest, while in the 2nd growing period dry weight was higher for all the treatments (Table 2). Similar results have been reported by Wang et al. (2009) who also observed an increase in dry weight of spinach plants when nitrogen: ammonium nitrogen changed from 1:0 to 0:1, while Szalai et al. (2010) have also reported an increase of stem dry matter in purslane when ammonium was the sole nitrogen source. Additionally, uncut plants (H3 treatment) had higher dry weight than cut plants in almost every treatment (apart from treatment F4), which could be attributed to the consumption of more carbohydrate reserves for regrowth, comparing to the uncut plants (Erice et al., 2011; Table 2).

The main detected sugars were glucose and sucrose, followed by fructose and trehalose, with significant differences between the fertilizer treatments for both growing periods and harvest stages (Table 3). In the 1st growing period, the highest sugar content was observed in plants of $\mathrm{H} 3$ treatment, mainly due to the highest content of fructose, glucose and trehalose, whereas the highest content of sucrose was observed during the 2 nd growing period. The lower sugars content during the 2nd growing period in the present study could be attributed to the reduced activity of sucrolytic enzymes due to higher temperatures that prevailed during this period as shown in Fig. 1 (Islam and Khan, 2001). However, regarding the effect of fertilizer treatments, no specific trend was observed among the studied harvest stages and growing periods. According to Gautier et al. (2008), Cocetta et al. (2017) and Rosales et al. (2011) the environmental conditions (temperature and light conditions) may have a detrimental effect on sugars content in vegetable crops. Similarly, Lombardo et al. (2016) reported variability in sugars in artichoke heads with different amounts of nitrogen fertilizers. In contrast, Fallovo et al. (2009) have reported that nutrient solution composition and growing season had a significant effect on total

Table 4

Composition in organic acids $(\mathrm{g} / \mathrm{kg}$ fresh weight) of Cichorium spinosum leaves (mean $\pm \mathrm{SD}$ ) in relation to nitrogen fertilization, number of harvests and growing period.

\begin{tabular}{|c|c|c|c|c|c|c|}
\hline \multicolumn{7}{|c|}{ Organic acids ( $\mathrm{g} / \mathrm{kg} \mathrm{fw})$} \\
\hline Harvest & Fertilization & Oxalic acid & Quinic acid & Malic acid & Citric acid & Total organic acids \\
\hline \multicolumn{7}{|c|}{ 1st Growing period } \\
\hline \multirow[t]{5}{*}{ H1 } & F1 & $5.50^{\mathrm{aB}}$ & $4.5^{\mathrm{aA}}$ & $2.67^{\mathrm{bB}}$ & $0.88^{\mathrm{cB}}$ & $13.5^{\mathrm{aB}}$ \\
\hline & F2 & $5.12^{\mathrm{bC}}$ & $3.6^{\mathrm{dC}}$ & $2.75^{\mathrm{aB}}$ & $0.97^{\mathrm{bA}}$ & $12.5^{\mathrm{bC}}$ \\
\hline & F3 & $5.06^{\mathrm{bC}}$ & $3.9^{\mathrm{cB}}$ & $2.10^{\mathrm{cC}}$ & $1.56^{\mathrm{aA}}$ & $12.6^{\mathrm{bC}}$ \\
\hline & F4 & $5.12^{\mathrm{bC}}$ & $4.0^{\mathrm{bB}}$ & $1.99^{\mathrm{dB}}$ & $0.66^{\mathrm{dA}}$ & $11.8^{\mathrm{cC}}$ \\
\hline & F5 & $4.32^{\mathrm{cC}}$ & $3.7^{\mathrm{dC}}$ & $1.84^{\mathrm{eB}}$ & $0.98^{\mathrm{bA}}$ & $10.9^{\mathrm{dC}}$ \\
\hline \multirow[t]{5}{*}{$\mathrm{H} 2$} & F1 & $5.30^{\mathrm{dC}}$ & $4.9^{\mathrm{cB}}$ & $1.21^{\mathrm{dC}}$ & $0.67^{\mathrm{bC}}$ & $12.0^{\mathrm{dC}}$ \\
\hline & F2 & $6.03^{\mathrm{aB}}$ & $5.4^{\mathrm{aA}}$ & $1.53^{\mathrm{bC}}$ & $0.68^{\mathrm{bC}}$ & $13.6^{\mathrm{bB}}$ \\
\hline & F3 & $5.9^{\mathrm{bB}}$ & $5.1^{\mathrm{bA}}$ & $2.24^{\mathrm{aB}}$ & $1.14^{\mathrm{aB}}$ & $14.4^{\mathrm{aB}}$ \\
\hline & F4 & $5.8^{\mathrm{cB}}$ & $4.5^{\mathrm{dA}}$ & $1.28^{\mathrm{cC}}$ & $0.44^{\mathrm{dB}}$ & $12.0^{\mathrm{dB}}$ \\
\hline & F5 & $5.71^{\mathrm{cB}}$ & $4.8^{\mathrm{cA}}$ & $1.19^{\mathrm{dC}}$ & $0.54^{\mathrm{cB}}$ & $12.2^{\mathrm{cB}}$ \\
\hline \multirow[t]{5}{*}{ H3 } & $\mathrm{F} 1$ & $6.3^{\mathrm{bA}}$ & $5.5^{\mathrm{aA}}$ & $3.02^{\mathrm{bA}}$ & $0.97^{\mathrm{aA}}$ & $15.8^{\mathrm{aA}}$ \\
\hline & F2 & $6.8^{\mathrm{aA}}$ & $4.5^{\mathrm{cB}}$ & $3.04^{\mathrm{bA}}$ & $0.86^{\mathrm{bB}}$ & $15.2^{\mathrm{bA}}$ \\
\hline & F3 & $6.8^{\mathrm{aA}}$ & $5.0^{\mathrm{bA}}$ & $3.36^{\mathrm{aA}}$ & $0.62^{\mathrm{cC}}$ & $15.8^{\mathrm{aA}}$ \\
\hline & F4 & $6.4^{\mathrm{bA}}$ & $3.9^{\mathrm{eC}}$ & $2.29^{\mathrm{cA}}$ & $0.34^{\mathrm{eC}}$ & $12.9^{\mathrm{cA}}$ \\
\hline & F5 & $5.9^{\mathrm{cA}}$ & $4.4^{\mathrm{dB}}$ & $2.13^{\mathrm{dA}}$ & $0.39^{\mathrm{dC}}$ & $12.8^{\mathrm{dA}}$ \\
\hline \multicolumn{7}{|c|}{ 2nd Growing period } \\
\hline \multirow[t]{5}{*}{$\mathrm{H} 1$} & $\mathrm{~F} 1$ & $6.2^{\mathrm{d}^{*}}$ & $4.6^{\mathrm{d}}$ & $4.4^{\mathrm{b}^{*}}$ & $1.12^{\mathrm{c}^{*}}$ & $16.3^{\mathrm{d}^{*}}$ \\
\hline & F2 & $7.4^{\mathrm{a}^{\mathrm{a}}}$ & $5.2^{\mathrm{b}^{*}}$ & $4.9^{\mathrm{a}^{\mathrm{*}}}$ & $1.39^{\mathrm{a}^{\mathrm{k}}}$ & $18.9^{\mathrm{a}^{*}}$ \\
\hline & F3 & $6.7^{\mathrm{c}^{*}}$ & $5.9^{\mathrm{a}^{\mathrm{k}}}$ & $3.8^{\mathrm{d}^{*}}$ & $0.90^{\mathrm{d}^{*}}$ & $17.3^{\mathrm{b}^{*}}$ \\
\hline & F4 & $7.0^{\mathrm{b}^{*}}$ & $4.1^{\mathrm{e}}$ & $3.9^{c^{*}}$ & $0.76^{\mathrm{e}^{*}}$ & $15.8^{\mathrm{e}^{*}}$ \\
\hline & F5 & $7.3^{\mathrm{a}^{\mathrm{*}}}$ & $4.9^{c^{k}}$ & $3.6^{\mathrm{e}^{*}}$ & $1.16^{\mathrm{b}^{*}}$ & $17.0^{c^{*}}$ \\
\hline \multicolumn{2}{|c|}{ Standard error } & 0.18 & 0.14 & 0.24 & 0.07 & 0.49 \\
\hline
\end{tabular}

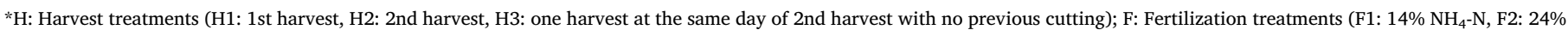

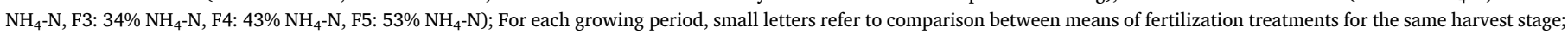

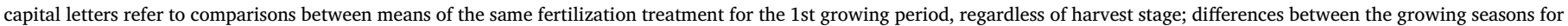
H1 treatment and the same fertilization treatment are indicated by the use of $(*)$ symbol. Mean separation was made with Tukey HSD test at $\mathrm{p}<.05$. 
carbohydrate and specific sugars content (except for sucrose and fructose, respectively).

The main detected organic acids were oxalic and quinic acid, followed by malic and citric acid, with significant differences between the fertilizer treatments for both growing periods and harvest stages (Table 4). Traces of fumaric acid and ascorbic acid were also detected (data not shown). At the 1st growing period, the highest malic, and total organic acids content was observed in plants of $\mathrm{H} 3$ treatment, while this content was higher in the 2nd growing period, regardless of fertilizer treatments, mostly due to the higher content of malic acid and to a lesser extent to oxalic acid content. The increase of malic acid with increasing temperatures has been reported in strawberry fruit (Wang and Camp, 2000), which was also the case in the present study, while (Szalai et al., 2010) have suggested that increasing ammonium nitrogen in nutrient solution resulted in higher malic acid and lower oxalic acid contents in purslane leaves. Oxalic acid was detected in low amounts, therefore the effect of fertilizer treatments was less profound comparing to other studies where higher amounts of ammonium nitrogen have been reported to decrease oxalic acid content (Palaniswamy et al., 2004; Szalai et al., 2010; Zhang et al., 2005). The effect of nitrogen source on organic acids content is associated: (i) with assimilation procedures in roots, where nitrates are reduced by nitrate reductase and organic acids are produced and accumulated in the upper parts of the plant as the result of this reaction (Fontana et al., 2006), (ii) with inhibition of oxalic acid oxidase activity by nitrate ions (Libert and Franceschi, 1987), and (iii) with induction of organic acids biosynthesis for further amino acids production and prevention of alklanization (Scheible, 1997).

Regarding the fatty acids composition, the main identified fatty acids were alpha-linolenic acid (C18:3n3), followed by linoleic acid (C18:2n6c) and palmitic acid (C16:0), with significant differences between the fertilizer treatments for both growing periods and harvest stages (Table 5). Moreover, $\alpha$-linolenic acid was the most abundant fatty acid with its content ranging from 65 to $72 \%$. At the 1st growing period, the lowest content of total polyunsaturated fatty acids (PUFA) was recorded in plants of $\mathrm{H} 3$ treatment, while PUFA content was higher in the 1st growing period than the 2nd growing season, regardless of the fertilizer treatments (Table 5). Fontana et al. (2006) have reported a significant decrease of palmitic acid in purslane plants (whole upper part) when nitrate: ammonium nitrogen ratio switched from 1.5 to 0.75 , which was also the case in our study for the 1 st growing period (treatments F3 and F5). In contrast, Szalai et al. (2010) reported that nutrient solution composition did not affect fatty acids profile of purslane leaves. This difference could be explained by the shorter growth cycle of purslane comparing to $C$. spinosum, as well as by the different growing system implemented in that study (hydroponic system).

The main fatty acids detected in the present study have been previously reported for C. spinosum leaves in our previous study (Petropoulos et al., 2016); however, the fatty acids profile of this study differed from the previous reports, especially regarding alpha-linolenic and linoleic acid contents. These differences could be attributed to the studied genotypes and growing conditions, as well as to fertilizer treatments, which differed from the above mentioned studies.

Tocopherol contents are presented in Table 6. During the 1st growing period, alpha- and beta- and gamma-tocopherols content was higher in $\mathrm{H} 3$ treatment. Furthermore, in $\mathrm{H} 1$ treatment, alpha- and betaand gamma-tocopherol contents were lower in treatment F1, whereas in $\mathrm{H} 2$ treatment, alpha- and beta- and gamma-tocopherols were lower when treatments F1 and F2 were applied. In contrast, during the 2nd growing period gamma- and delta-tocopherols content was higher in treatment F4, whereas alpha- and beta-tocopherols were higher in treatment F2. In addition, alpha- and beta-tocopherols content was significantly higher in the 2nd growing period, while gamma- and delta-tocopherol differed between fertilizer treatments and growing periods.

According to Szalai et al. (2010), increasing ammonium nitrogen

Table 5

The main fatty acids (relative percentage\%) of Cichorium spinosum leaves (mean \pm SD) in relation to nitrogen fertilization, number of harvests and growing period.

\begin{tabular}{|c|c|c|c|c|c|c|c|c|c|c|}
\hline \multirow[b]{2}{*}{ Harvest } & \multirow[b]{2}{*}{ Fertilization } & \multicolumn{9}{|c|}{ Fatty acids } \\
\hline & & $\mathrm{C} 16: 0$ & C18:0 & $\mathrm{C} 18: \ln 9 \mathrm{c}$ & $\mathrm{C} 18: 2 \mathrm{n} 6 \mathrm{c}$ & C18:3n3 & $\mathrm{C} 24: 0$ & Total SFA & Total MUFA & Total PUFA \\
\hline \multicolumn{11}{|c|}{ 1st Growing period } \\
\hline \multirow[t]{5}{*}{$\mathrm{H} 1$} & $\mathrm{~F} 1$ & $8.25^{\mathrm{aB}}$ & $0.913^{\mathrm{cB}}$ & $1.31^{\mathrm{aA}}$ & $15.50^{\mathrm{aB}}$ & $71.09^{\mathrm{eB}}$ & $0.75^{\mathrm{abA}}$ & $11.47^{\mathrm{cB}}$ & $1.53^{\mathrm{bA}}$ & $87.00^{\mathrm{bB}}$ \\
\hline & $\mathrm{F} 2$ & $7.83^{\mathrm{bB}}$ & $1.08^{\mathrm{aA}}$ & $1.21^{\mathrm{bA}}$ & $13.54^{\mathrm{dC}}$ & $72.40^{\mathrm{bA}}$ & $0.63^{\mathrm{cB}}$ & $11.37^{\mathrm{cB}}$ & $2.30^{\mathrm{aA}}$ & $86.33^{\mathrm{eB}}$ \\
\hline & F3 & $8.22^{\mathrm{aC}}$ & $1.03^{\mathrm{bA}}$ & $1.13^{\mathrm{cA}}$ & $14.92^{\mathrm{bC}}$ & $71.39^{\mathrm{cA}}$ & $0.75^{\mathrm{abA}}$ & $11.87^{\mathrm{bB}}$ & $1.45^{\mathrm{cA}}$ & $86.68^{\mathrm{cB}}$ \\
\hline & $\mathrm{F} 4$ & $8.19^{\mathrm{aB}}$ & $1.02 \mathrm{~b}^{\mathrm{cB}}$ & $1.09^{\mathrm{dB}}$ & $14.90^{\mathrm{bC}}$ & $71.22^{\mathrm{dA}}$ & $0.82^{\mathrm{aB}}$ & $12.07^{\mathrm{aB}}$ & $1.42^{\mathrm{dB}}$ & $86.51^{\mathrm{dB}}$ \\
\hline & F5 & $7.55^{\mathrm{cC}}$ & $0.91 b^{\mathrm{cB}}$ & $0.97^{\mathrm{eC}}$ & $13.89^{\mathrm{cC}}$ & $73.73^{\mathrm{aA}}$ & $0.70^{\mathrm{bcB}}$ & $10.77^{\mathrm{dB}}$ & $1.22^{\mathrm{eC}}$ & $88.01^{\mathrm{aA}}$ \\
\hline \multirow[t]{5}{*}{$\mathrm{H} 2$} & $\mathrm{~F} 1$ & $7.92^{\mathrm{bC}}$ & $0.91^{\mathrm{bB}}$ & $1.18^{\mathrm{bB}}$ & $15.41^{\mathrm{dC}}$ & $71.78^{\mathrm{aA}}$ & $0.68^{\mathrm{aA}}$ & $11.00^{\mathrm{bC}}$ & $1.45^{\mathrm{cB}}$ & $87.55^{\mathrm{aA}}$ \\
\hline & $\mathrm{F} 2$ & $7.99^{\mathrm{bB}}$ & $0.87^{\mathrm{cB}}$ & $1.26^{\mathrm{aA}}$ & $15.88^{\mathrm{aB}}$ & $71.25^{\mathrm{bB}}$ & $0.66^{\mathrm{aB}}$ & $10.96^{\mathrm{bC}}$ & $1.57^{\mathrm{aB}}$ & $87.47^{\mathrm{aA}}$ \\
\hline & F3 & $8.42^{\mathrm{aB}}$ & $0.98^{\mathrm{aB}}$ & $1.07^{\mathrm{cB}}$ & $15.35^{\mathrm{eB}}$ & $71.29^{\mathrm{bB}}$ & $0.67^{\mathrm{aB}}$ & $11.57^{\mathrm{aC}}$ & $1.38^{\mathrm{eB}}$ & $87.05^{\mathrm{bA}}$ \\
\hline & $\mathrm{F} 4$ & $8.02^{\mathrm{bC}}$ & $0.90^{\mathrm{bcC}}$ & $1.17^{\mathrm{bA}}$ & $15.82^{\mathrm{bB}}$ & $71.20^{\mathrm{bA}}$ & $0.69^{\mathrm{aC}}$ & $11.10^{\mathrm{bC}}$ & $1.51^{\mathrm{bA}}$ & $87.39^{\mathrm{aA}}$ \\
\hline & F5 & $8.00^{\mathrm{bB}}$ & $0.85^{\mathrm{dC}}$ & $1.09^{\mathrm{cA}}$ & $15.75^{\mathrm{cB}}$ & $71.27^{\mathrm{bB}}$ & $0.71^{\mathrm{aB}}$ & $11.12^{\mathrm{bB}}$ & $1.41^{\mathrm{dB}}$ & $87.48^{\mathrm{aB}}$ \\
\hline \multirow[t]{5}{*}{ H3 } & $\mathrm{F} 1$ & $9.10^{\mathrm{cA}}$ & $0.94^{\mathrm{cA}}$ & $0.96^{\mathrm{bcC}}$ & $16.13^{\mathrm{eA}}$ & $69.66^{\mathrm{aC}}$ & $0.72^{\mathrm{bA}}$ & $12.45^{\mathrm{cA}}$ & $1.33^{\mathrm{bC}}$ & $86.22^{\mathrm{aC}}$ \\
\hline & $\mathrm{F} 2$ & $9.57^{\mathrm{bA}}$ & $1.05^{\mathrm{abA}}$ & $1.20^{\mathrm{aA}}$ & $16.28^{\mathrm{dA}}$ & $68.58^{\mathrm{bC}}$ & $0.78^{\mathrm{bA}}$ & $12.99^{\mathrm{bA}}$ & $1.54^{\mathrm{aB}}$ & $85.48^{\mathrm{bC}}$ \\
\hline & F3 & $10.15^{\mathrm{aA}}$ & $1.04^{\mathrm{abA}}$ & $0.99^{\mathrm{bC}}$ & $16.91^{\mathrm{cA}}$ & $67.43^{\mathrm{cC}}$ & $0.79^{\mathrm{bA}}$ & $13.86^{\mathrm{aA}}$ & $1.34^{\mathrm{bB}}$ & $84.80^{\mathrm{cdC}}$ \\
\hline & $\mathrm{F} 4$ & $9.95^{\mathrm{aA}}$ & $1.08^{\mathrm{aA}}$ & $0.90^{\mathrm{cC}}$ & $17.75^{\mathrm{bA}}$ & $66.44^{\mathrm{eB}}$ & $0.92^{\mathrm{aA}}$ & $14.10^{\mathrm{aA}}$ & $1.32^{\mathrm{bC}}$ & $84.58^{\mathrm{dC}}$ \\
\hline & F5 & $9.56^{\mathrm{bA}}$ & $1.00^{\mathrm{bA}}$ & $1.03^{\mathrm{bA}}$ & $18.31^{\mathrm{aA}}$ & $66.56^{\mathrm{dC}}$ & $0.76^{\mathrm{bA}}$ & $13.27^{\mathrm{bA}}$ & $1.49^{\mathrm{aA}}$ & $85.25^{\mathrm{bcC}}$ \\
\hline \multicolumn{11}{|c|}{ 2nd Growing period } \\
\hline \multirow[t]{5}{*}{ H1 } & $\mathrm{F} 1$ & $10.03^{c_{*}}$ & $1.01^{\mathrm{c} *}$ & $1.30^{\mathrm{c}}$ & $16.16^{\mathrm{e} *}$ & $68.38^{\mathrm{a} *}$ & $0.71^{\mathrm{b} *}$ & $13.48^{c_{*}}$ & $1.65^{\mathrm{d} *}$ & $84.87^{\mathrm{b} *}$ \\
\hline & $\mathrm{F} 2$ & $10.28^{\mathrm{bc} *}$ & $1.09^{\mathrm{a} *}$ & $1.14^{\mathrm{d} *}$ & $17.01^{\mathrm{d} *}$ & $67.31^{c_{*}}$ & $0.62^{\mathrm{c}}$ & $13.88^{\mathrm{b} *}$ & $1.47^{\mathrm{e} *}$ & $84.65^{\mathrm{b} *}$ \\
\hline & F3 & $9.54^{\mathrm{d} *}$ & $0.93^{\mathrm{d}_{*}}$ & $1.39^{\mathrm{a} *}$ & $17.39^{c_{*}}$ & $67.65^{\mathrm{b} *}$ & $0.76^{\mathrm{ab}}$ & $12.88^{\mathrm{d}_{*}}$ & $1.77^{\mathrm{b} *}$ & $85.35^{\mathrm{a} \%}$ \\
\hline & F4 & $10.69^{\mathrm{a} *}$ & $1.05^{\mathrm{b}}$ & $1.28^{\mathrm{c} *}$ & $18.69^{\mathrm{a} *}$ & $64.71^{\mathrm{d}_{*}}$ & $0.76^{\mathrm{ab}}$ & $14.51^{\mathrm{a} *}$ & $1.73^{\mathrm{c} *}$ & $83.76^{\mathrm{c} *}$ \\
\hline & F5 & $10.61^{\mathrm{ab} *}$ & $0.99^{\mathrm{c} *}$ & $1.346^{\mathrm{b} *}$ & $18.40^{\mathrm{b} *}$ & $64.91^{\mathrm{d}_{*}}$ & $0.79^{\mathrm{a} *}$ & $14.42^{\mathrm{a} *}$ & $1.89^{\mathrm{a} *}$ & $83.70^{c *}$ \\
\hline \multicolumn{2}{|c|}{ Standard error } & 0.24 & 0.02 & 0.03 & 0.32 & 0.58 & 0.02 & 0.29 & 0.05 & 0.30 \\
\hline
\end{tabular}

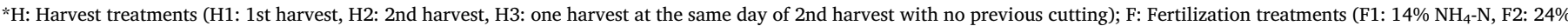

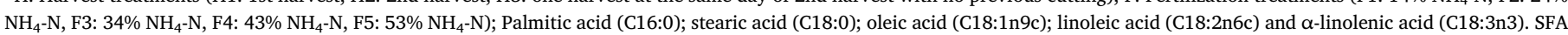

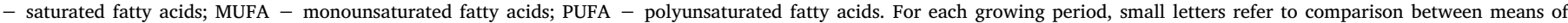

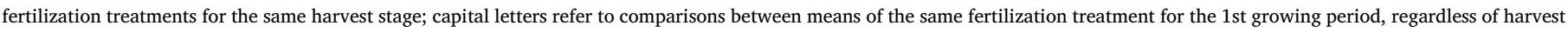

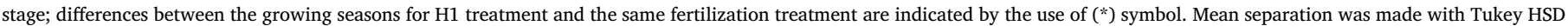
test at $\mathrm{p}<.05$. 
Table 6

Tocopherols content (mg/kg fw) of Cichorium spinosum leaves (mean $\pm \mathrm{SD}$ ) in relation to nitrogen fertilization, number of harvests and growing period.

\begin{tabular}{|c|c|c|c|c|c|c|}
\hline \multirow[b]{2}{*}{ Harvest } & \multirow[b]{2}{*}{ Fertilization } & \multicolumn{4}{|c|}{ Tocopherols (mg/kg fw) } & \multirow[b]{2}{*}{ Total Tocopherols } \\
\hline & & alpha-Tocopherol & beta- Tocopherol & gamma-Tocopherol & delta-Tocopherol & \\
\hline \multicolumn{7}{|c|}{ 1st Growing period } \\
\hline \multirow[t]{5}{*}{$\mathrm{H} 1$} & $\mathrm{~F} 1$ & $0.67^{\mathrm{dC}}$ & $0.050^{\mathrm{cB}}$ & $2.80^{\mathrm{eB}}$ & $0.016^{\mathrm{cB}}$ & $3.54^{\mathrm{eC}}$ \\
\hline & $\mathrm{F} 2$ & $1.13^{\mathrm{cB}}$ & $0.069^{\mathrm{aB}}$ & $3.87^{\mathrm{cB}}$ & $0.016^{\mathrm{cA}}$ & $5.08^{\mathrm{cB}}$ \\
\hline & F3 & $1.45^{\mathrm{aC}}$ & $0.052^{\mathrm{bcC}}$ & $4.78^{\mathrm{aA}}$ & $0.028^{\mathrm{aA}}$ & $6.31^{\mathrm{aB}}$ \\
\hline & F4 & $1.41^{\mathrm{bB}}$ & $0.056^{\mathrm{bB}}$ & $4.34^{\mathrm{bB}}$ & $0.018^{\mathrm{cB}}$ & $5.82^{\mathrm{bB}}$ \\
\hline & F5 & $1.41^{\mathrm{bB}}$ & $0.051^{\mathrm{cB}}$ & $3.23^{\mathrm{dC}}$ & $0.022^{\mathrm{bA}}$ & $4.71^{\mathrm{dC}}$ \\
\hline \multirow[t]{5}{*}{$\mathrm{H} 2$} & $\mathrm{~F} 1$ & $0.95^{\mathrm{dB}}$ & $0.028^{\mathrm{dC}}$ & $2.75^{\mathrm{eC}}$ & $0.009^{\mathrm{cC}}$ & $3.74^{\mathrm{eB}}$ \\
\hline & $\mathrm{F} 2$ & $0.95^{\mathrm{dC}}$ & $0.038^{\mathrm{cC}}$ & $2.80^{\mathrm{dC}}$ & $0.016^{\mathrm{aA}}$ & $3.80^{\mathrm{dC}}$ \\
\hline & F3 & $1.71^{\mathrm{aB}}$ & $0.064^{\mathrm{aB}}$ & $4.42^{\mathrm{aB}}$ & $0.015^{\mathrm{bB}}$ & $6.21^{\mathrm{aB}}$ \\
\hline & F4 & $1.33^{\mathrm{bC}}$ & $0.053^{\mathrm{bB}}$ & $3.01^{\mathrm{cC}}$ & $0.006^{\mathrm{dC}}$ & $4.40^{\mathrm{cC}}$ \\
\hline & F5 & $1.28^{\mathrm{cC}}$ & $0.034^{\mathrm{cC}}$ & $4.31^{\mathrm{bB}}$ & $0.016^{\mathrm{aB}}$ & $5.65^{\mathrm{bB}}$ \\
\hline \multirow[t]{5}{*}{ H3 } & $\mathrm{F} 1$ & $4.04^{\mathrm{cA}}$ & $0.072^{\mathrm{dA}}$ & $8.29^{\mathrm{aA}}$ & $0.024^{\mathrm{aA}}$ & $12.43^{\mathrm{aA}}$ \\
\hline & $\mathrm{F} 2$ & $2.45^{\mathrm{eA}}$ & $0.077^{\mathrm{dA}}$ & $4.27^{\mathrm{dA}}$ & $0.012^{\mathrm{cB}}$ & $6.81^{\mathrm{dA}}$ \\
\hline & F3 & $4.74^{\mathrm{bA}}$ & $0.123^{\mathrm{bA}}$ & $3.49^{\mathrm{eC}}$ & $0.012^{\mathrm{cC}}$ & $8.36^{\mathrm{cA}}$ \\
\hline & F4 & $5.27^{\mathrm{aA}}$ & $0.141^{\mathrm{aA}}$ & $6.68^{\mathrm{bA}}$ & $0.020^{\mathrm{bA}}$ & $12.11^{\mathrm{bA}}$ \\
\hline & F5 & $3.56^{\mathrm{dA}}$ & $0.111^{\mathrm{cA}}$ & $4.63^{\mathrm{cA}}$ & $0.011^{\mathrm{cC}}$ & $8.32^{\mathrm{cA}}$ \\
\hline \multicolumn{7}{|c|}{ 2nd Growing period } \\
\hline \multirow[t]{5}{*}{$\mathrm{H} 1$} & $\mathrm{~F} 1$ & $8.59^{\mathrm{c} *}$ & $0.097^{\mathrm{d} *}$ & $3.67^{\mathrm{c} *}$ & $0.014^{\mathrm{b} *}$ & $12.37^{\mathrm{c} *}$ \\
\hline & $\mathrm{F} 2$ & $12.17^{\mathrm{a} *}$ & $0.230^{\mathrm{a} *}$ & $4.02^{\mathrm{b} *}$ & $0.014^{\mathrm{b} *}$ & $16.44^{\mathrm{a} *}$ \\
\hline & F3 & $5.49^{\mathrm{e} *}$ & $0.130^{\mathrm{c} *}$ & $1.72^{\mathrm{d} *}$ & $0.010^{\mathrm{c} *}$ & $7.35^{\mathrm{e} *}$ \\
\hline & $\mathrm{F} 4$ & $8.94^{\mathrm{b} *}$ & $0.138^{\mathrm{b} *}$ & $4.11^{\mathrm{a} *}$ & $0.023^{\mathrm{a} *}$ & $13.21^{\mathrm{b} *}$ \\
\hline & F5 & $7.68^{\mathrm{d} *}$ & $0.228^{\mathrm{a} *}$ & $1.63^{\mathrm{e} *}$ & $0.006^{\mathrm{d} *}$ & $9.55^{d *}$ \\
\hline \multicolumn{2}{|c|}{ Standard error } & 0.335 & 0.013 & 0.34 & 0.001 & 0.83 \\
\hline
\end{tabular}

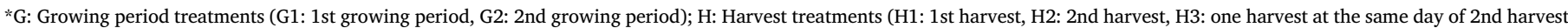

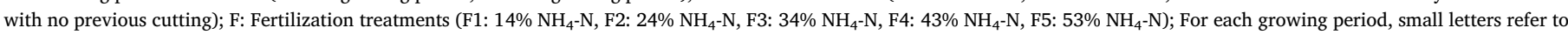

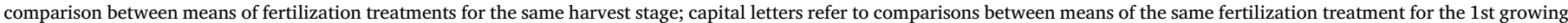

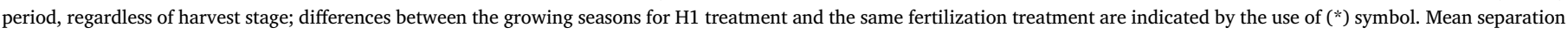
was made with Tukey HSD test at $\mathrm{p}<.05$.

Table 7

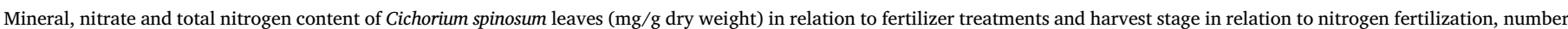
of harvests and growing period.

\begin{tabular}{|c|c|c|c|c|c|c|c|c|c|}
\hline \multirow[b]{2}{*}{ Harvest } & \multirow[b]{2}{*}{ Fertilization } & \multicolumn{8}{|c|}{ Mineral and nitrate content } \\
\hline & & $\mathrm{K}$ & $\mathrm{Ca}$ & $\mathrm{Mg}$ & $\mathrm{Zn}$ & $\mathrm{Mn}$ & $\mathrm{Fe}$ & $\mathrm{NO}_{3}{ }^{-}$ & Total N \\
\hline \multicolumn{10}{|c|}{ 1st Growing period } \\
\hline \multirow[t]{5}{*}{$\mathrm{H} 1$} & $\mathrm{~F} 1$ & $46.0^{\mathrm{aA}}$ & $19.5^{\mathrm{aA}}$ & $4.8^{\mathrm{aA}}$ & $0.028^{\mathrm{aA}}$ & $0.096^{\mathrm{abB}}$ & $0.057^{\mathrm{cB}}$ & $6.75^{\mathrm{abA}}$ & $26^{\mathrm{bB}}$ \\
\hline & $\mathrm{F} 2$ & $53.3^{\mathrm{aA}}$ & $18.1^{\mathrm{aA}}$ & $3.8^{\mathrm{aA}}$ & $0.040^{\mathrm{aA}}$ & $0.129^{\mathrm{aB}}$ & $0.073^{\mathrm{bcB}}$ & $7.30^{\mathrm{abA}}$ & $16^{\mathrm{cC}}$ \\
\hline & F3 & $52.0^{\mathrm{aA}}$ & $20.8^{\mathrm{aA}}$ & $4.1^{\mathrm{aA}}$ & $0.031^{\mathrm{aA}}$ & $0.113^{\mathrm{abB}}$ & $0.082^{\mathrm{bcB}}$ & $7.36^{\mathrm{abB}}$ & $34^{\mathrm{aB}}$ \\
\hline & F4 & $46.0^{\mathrm{aA}}$ & $14.8^{\mathrm{aA}}$ & $3.7^{\mathrm{aB}}$ & $0.033^{\mathrm{aA}}$ & $0.087^{\mathrm{bA}}$ & $0.096^{\mathrm{abB}}$ & $9.04^{\mathrm{aA}}$ & $32^{\mathrm{aB}}$ \\
\hline & F5 & $57.3^{\mathrm{aA}}$ & $16.1^{\mathrm{aA}}$ & $4.3^{\mathrm{aA}}$ & $0.031^{\mathrm{aA}}$ & $0.109^{\mathrm{abA}}$ & $0.120^{\mathrm{aA}}$ & $5.84^{\mathrm{bB}}$ & $29^{\mathrm{bB}}$ \\
\hline \multirow[t]{5}{*}{$\mathrm{H} 2$} & $\mathrm{~F} 1$ & $46.7^{\mathrm{aA}}$ & $17.4^{\mathrm{abA}}$ & $3.8^{\mathrm{abA}}$ & $0.030^{\mathrm{aA}}$ & $0.124^{\mathrm{bA}}$ & $0.100^{\mathrm{aA}}$ & $7.86^{\mathrm{abcA}}$ & $23^{\mathrm{bB}}$ \\
\hline & $\mathrm{F} 2$ & $44.0^{\mathrm{abB}}$ & $19.6^{\mathrm{aA}}$ & $3.6^{\mathrm{abA}}$ & $0.031^{\mathrm{aA}}$ & $0.149^{\mathrm{aA}}$ & $0.110^{\mathrm{aA}}$ & $6.94^{\mathrm{bcA}}$ & $30^{\mathrm{aB}}$ \\
\hline & F3 & $40.0^{\mathrm{abB}}$ & $18.4^{\mathrm{abA}}$ & $4.6^{\mathrm{aA}}$ & $0.034^{\mathrm{aA}}$ & $0.149^{\mathrm{aA}}$ & $0.121^{\mathrm{aA}}$ & $6.82^{\mathrm{cB}}$ & $32^{\mathrm{aB}}$ \\
\hline & F4 & $36.0^{\mathrm{bB}}$ & $13.3^{\mathrm{bA}}$ & $2.8^{\mathrm{bC}}$ & $0.022^{\mathrm{bB}}$ & $0.094^{\mathrm{cA}}$ & $0.113^{\mathrm{aA}}$ & $8.68^{\mathrm{aA}}$ & $25^{\mathrm{bC}}$ \\
\hline & F5 & $44.7^{\mathrm{abB}}$ & $15.5^{\mathrm{abA}}$ & $3.7^{\mathrm{abA}}$ & $0.031^{\mathrm{aA}}$ & $0.128^{\mathrm{bA}}$ & $0.110^{\mathrm{aA}}$ & $8.30^{\mathrm{abA}}$ & $29^{\mathrm{aB}}$ \\
\hline \multirow[t]{5}{*}{ H3 } & $\mathrm{F} 1$ & $45.0^{\mathrm{aA}}$ & $16.7^{\mathrm{aA}}$ & $3.4^{\mathrm{bA}}$ & $0.022^{\mathrm{aB}}$ & $0.093^{\mathrm{aB}}$ & $0.097^{\mathrm{abA}}$ & $5.63^{\mathrm{cA}}$ & $37^{\mathrm{bA}}$ \\
\hline & $\mathrm{F} 2$ & $42.7^{\mathrm{aB}}$ & $18.5^{\mathrm{aA}}$ & $3.4^{\mathrm{bA}}$ & $0.032^{\mathrm{aA}}$ & $0.118^{\mathrm{aC}}$ & $0.117^{\mathrm{aA}}$ & $7.44^{\mathrm{bcA}}$ & $37^{\mathrm{bA}}$ \\
\hline & F3 & $47.0^{\mathrm{aB}}$ & $22.0^{\mathrm{aA}}$ & $4.6^{\mathrm{aA}}$ & $0.024^{\mathrm{aA}}$ & $0.108^{\mathrm{aB}}$ & $0.083^{\mathrm{abB}}$ & $9.93^{\mathrm{aA}}$ & $43^{\mathrm{aA}}$ \\
\hline & F4 & $35.0^{\mathrm{aB}}$ & $18.4^{\mathrm{aA}}$ & $5.0^{\mathrm{aA}}$ & $0.031^{\mathrm{aA}}$ & $0.109^{\mathrm{aA}}$ & $0.068^{\mathrm{bC}}$ & $8.00^{\mathrm{abA}}$ & $36^{\mathrm{bA}}$ \\
\hline & F5 & $39.0^{\mathrm{aB}}$ & $17.1^{\mathrm{aA}}$ & $3.8^{\mathrm{bA}}$ & $0.030^{\mathrm{aA}}$ & $0.115^{\mathrm{aA}}$ & $0.066^{\mathrm{bB}}$ & $6.08^{\mathrm{bcB}}$ & $36^{\mathrm{bA}}$ \\
\hline \multicolumn{10}{|c|}{ 2nd Growing period } \\
\hline \multirow[t]{5}{*}{ H1 } & $\mathrm{F} 1$ & $28.0^{\mathrm{a} *}$ & $38.5^{\mathrm{a} *}$ & $4.8^{\mathrm{b}}$ & $0.021^{\mathrm{a} *}$ & $0.078^{\mathrm{b} *}$ & $0.078^{\mathrm{a} *}$ & $7.37^{\mathrm{b}}$ & $39^{\mathrm{a} *}$ \\
\hline & $\mathrm{F} 2$ & $27.0^{\mathrm{a} *}$ & $41.7^{\mathrm{a} *}$ & $5.0^{\mathrm{b}^{*}}$ & $0.019^{\mathrm{a} *}$ & $0.088^{\mathrm{ab}_{*}}$ & $0.071^{\mathrm{b}}$ & $6.95^{\mathrm{c}}$ & $34^{\mathrm{b} *}$ \\
\hline & F3 & $32.0^{\mathrm{a} *}$ & $35.9^{\mathrm{ab} *}$ & $4.7^{\mathrm{b}}$ & $0.022^{\mathrm{a} *}$ & $0.092^{\mathrm{a} *}$ & $0.080^{\mathrm{a}}$ & $7.73^{\mathrm{ab}}$ & $39^{a *}$ \\
\hline & F4 & $25.0^{\mathrm{a} *}$ & $27.2^{\mathrm{c} *}$ & $4.1^{\mathrm{c}}$ & $0.020^{\mathrm{a} *}$ & $0.096^{\mathrm{a} *}$ & $0.064^{\mathrm{c} *}$ & $8.74^{\mathrm{a}}$ & $40^{\mathrm{a} *}$ \\
\hline & F5 & $27.0^{\mathrm{a} *}$ & $29.3^{\mathrm{bc}_{*}}$ & $5.6^{\mathrm{a} *}$ & $0.022^{\mathrm{a} *}$ & $0.097^{\mathrm{a}^{*}}$ & $0.072^{\mathrm{b} *}$ & $6.23^{\mathrm{d}}$ & $38^{\mathrm{a} *}$ \\
\hline \multicolumn{2}{|c|}{ Standard error } & 2.09 & 1.70 & 0.55 & 0.001 & 0.004 & 0.005 & 0.25 & 1.49 \\
\hline
\end{tabular}

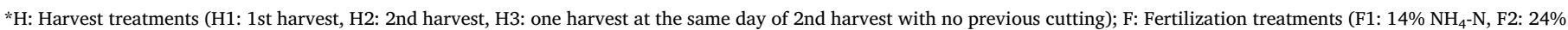

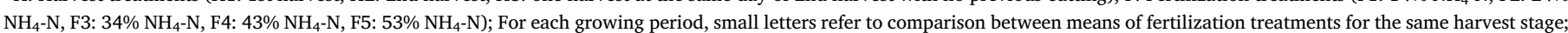

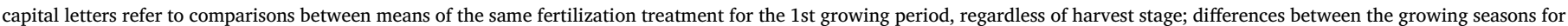
$\mathrm{H} 1$ treatment and the same fertilization treatment are indicated by the use of $\left({ }^{*}\right)$ symbol. Mean separation was made with Tukey HSD test at $\mathrm{p}<.05$. 
Table 8

Antioxidant properties of Cichorium spinosum leaves in relation to nitrogen fertilization, number of harvests and growing period.

\begin{tabular}{|c|c|c|c|c|c|}
\hline \multirow[b]{2}{*}{ Harvest } & \multirow[b]{2}{*}{ Fertilization } & \multirow{2}{*}{$\begin{array}{l}\begin{array}{l}\text { Reducing } \\
\text { power }\end{array} \\
\text { Ferricyanide/ } \\
\text { Prussian blue } \\
\left(\mathrm{EC}_{50} ; \mathrm{mg} /\right. \\
\mathrm{mL})\end{array}$} & \multicolumn{2}{|c|}{$\begin{array}{l}\text { Radical scavenging } \\
\text { activity }\end{array}$} & \multirow{2}{*}{$\begin{array}{l}\text { Lipid } \\
\text { peroxidation } \\
\text { inhibition } \\
\text { TBARS }\left(\mathrm{EC}_{50} \text {; }\right. \\
\mathrm{mg} / \mathrm{mL})\end{array}$} \\
\hline & & & $\begin{array}{l}\mathrm{DPPH} \\
\text { scavenging } \\
\text { activity } \\
\left(\mathrm{EC}_{50} ; \mathrm{mg} /\right. \\
\mathrm{mL})\end{array}$ & $\begin{array}{l}\beta- \\
\text { carotene/ } \\
\text { linoleate } \\
\left(\mathrm{EC}_{50} ;\right. \\
\mathrm{mg} / \mathrm{mL})\end{array}$ & \\
\hline \multicolumn{6}{|c|}{ 1st Growing period } \\
\hline \multirow[t]{5}{*}{ H1 } & F1 & $1.82^{\mathrm{aA}}$ & $4.00^{\mathrm{aA}}$ & $0.90^{\mathrm{bA}}$ & $0.78^{\mathrm{aA}}$ \\
\hline & $\mathrm{F} 2$ & $1.37^{\mathrm{bA}}$ & $3.84^{\mathrm{bA}}$ & $0.84^{\mathrm{eA}}$ & $0.72^{\mathrm{bB}}$ \\
\hline & F3 & $0.94^{\mathrm{dB}}$ & $2.29^{\mathrm{dA}}$ & $0.86^{\mathrm{cdB}}$ & $0.66^{\mathrm{cB}}$ \\
\hline & $\mathrm{F} 4$ & $0.96^{\mathrm{dB}}$ & $2.21^{\mathrm{eB}}$ & $0.87^{\mathrm{cA}}$ & $0.66^{\mathrm{cA}}$ \\
\hline & F5 & $1.17^{\mathrm{cA}}$ & $2.78^{\mathrm{cB}}$ & $0.93^{\mathrm{aA}}$ & $0.79^{\mathrm{aA}}$ \\
\hline \multirow[t]{5}{*}{$\mathrm{H} 2$} & $\mathrm{~F} 1$ & $1.25^{\mathrm{bB}}$ & $3.80^{\mathrm{aB}}$ & $0.91^{\mathrm{cA}}$ & $0.73^{\mathrm{bB}}$ \\
\hline & $\mathrm{F} 2$ & $1.18^{\mathrm{bB}}$ & $2.81^{\mathrm{dB}}$ & $1.01^{\mathrm{aB}}$ & $0.85^{\mathrm{aA}}$ \\
\hline & F3 & $0.96^{\mathrm{eA}}$ & $1.69^{\mathrm{eB}}$ & $0.96^{\mathrm{bA}}$ & $0.71^{\mathrm{bA}}$ \\
\hline & $\mathrm{F} 4$ & $1.12^{\mathrm{dA}}$ & $2.94^{\mathrm{cA}}$ & $0.70^{\mathrm{eC}}$ & $0.48^{\mathrm{dB}}$ \\
\hline & F5 & $1.15^{\mathrm{cB}}$ & $3.15^{\mathrm{bA}}$ & $0.88^{\mathrm{dB}}$ & $0.52^{\mathrm{cB}}$ \\
\hline \multirow[t]{5}{*}{ H3 } & $\mathrm{F} 1$ & $0.79^{\mathrm{cC}}$ & $1.15^{\mathrm{dC}}$ & $0.79^{\mathrm{bB}}$ & $0.47^{\mathrm{aC}}$ \\
\hline & $\mathrm{F} 2$ & $0.89^{\mathrm{aC}}$ & $1.18^{\mathrm{cdC}}$ & $0.73^{\mathrm{cC}}$ & $0.44^{\mathrm{bC}}$ \\
\hline & F3 & $0.84^{\mathrm{bC}}$ & $2.26^{\mathrm{aA}}$ & $0.85^{\mathrm{aB}}$ & $0.39^{\mathrm{cC}}$ \\
\hline & F4 & $0.69^{\mathrm{dC}}$ & $1.24^{\mathrm{cC}}$ & $0.83^{\mathrm{aB}}$ & $0.34^{\mathrm{dC}}$ \\
\hline & F5 & $0.69^{\mathrm{dC}}$ & $1.85^{\mathrm{bC}}$ & $0.52^{\mathrm{dC}}$ & $0.34^{\mathrm{dC}}$ \\
\hline \multicolumn{6}{|c|}{ 2nd Growing period } \\
\hline \multirow[t]{5}{*}{ H1 } & $\mathrm{F} 1$ & $0.19^{\mathrm{d} *}$ & $0.40^{\mathrm{b} *}$ & $0.18^{\mathrm{e}_{*}}$ & $0.17^{\mathrm{e} *}$ \\
\hline & $\mathrm{F} 2$ & $0.23^{c_{*}}$ & $0.34^{\mathrm{c}_{*}}$ & $0.24 d^{*}$ & $0.24^{\mathrm{d} *}$ \\
\hline & F3 & $0.39^{a *}$ & $0.39^{\mathrm{b} *}$ & $0.94^{\mathrm{a} *}$ & $0.37^{\mathrm{b} *}$ \\
\hline & F4 & $0.30^{\mathrm{b} *}$ & $0.41^{\mathrm{b} *}$ & $0.84^{\mathrm{b} *}$ & $0.36^{\mathrm{c} *}$ \\
\hline & F5 & $0.30^{\mathrm{b} *}$ & $0.56^{\mathrm{a} *}$ & $0.75^{\mathrm{c}_{*}}$ & $0.43^{\mathrm{a} *}$ \\
\hline \multicolumn{2}{|c|}{ Standard error } & 0.096 & 0.276 & 0.049 & 0.045 \\
\hline
\end{tabular}

*G: Growing period treatments (G1: 1st growing period, G2: 2nd growing period); H: Harvest treatments (H1: 1st harvest, H2: 2nd harvest, H3: one harvest at the same day of 2nd harvest with no previous cutting); F: Fertilization treatments (F1: $14 \% \mathrm{NH}_{4}-\mathrm{N}, \mathrm{F} 2$ : 24\% $\mathrm{NH}_{4}$-N, F3: 34\% $\left.\mathrm{NH}_{4}-\mathrm{N}, \mathrm{F} 4: 43 \% \mathrm{NH}_{4}-\mathrm{N}, \mathrm{F} 5: 53 \% \mathrm{NH}_{4}-\mathrm{N}\right)$.

The antioxidant activity was expressed as $\mathrm{EC}_{50}$ values, what means that higher values correspond to lower reducing power or antioxidant potential. Trolox EC 50 values: $41 \mu \mathrm{g}$ / $\mathrm{mL}$ (reducing power), $42 \mu \mathrm{g} / \mathrm{mL}$ (DPPH scavenging activity), $18 \mu \mathrm{g} / \mathrm{mL}$ ( $\beta$-carotene bleaching inhibition) and $23 \mu \mathrm{g} / \mathrm{mL}$ (TBARS inhibition).

For each growing period, small letters refer to comparison between means of fertilization treatments for the same harvest stage; capital letters refer to comparisons between means of the same fertilization treatment for the 1st growing period, regardless of harvest stage; differences between the growing seasons for $\mathrm{H} 1$ treatment and the same fertilization treatment are indicated by the use of $(*)$ symbol. Mean separation was made with Tukey HSD test at $\mathrm{p}<.05$.

content in nutrient solution resulted in higher amounts of both alphaand gamma-tocopherols in purslane leaves comparing to nutrient solution where only nitrate nitrogen was applied. Moreover, they suggest the increase of tocopherol is dependent on nitrogen source and on genotype, which complicates the discussion of tocopherol composition and content. In addition, Hussain et al. (2014) have confirmed that nitrogen source (ureic or ammonium nitrogen) and application rate may significantly affect alpha-, gamma- and total tocopherols content of rapeseeds oil. Furthermore, total tocopherols content was significantly higher in the 2nd growing period in comparison to the 1st growing period. This may be attributed to higher air temperatures that prevailed in the 2nd growing period. In a recent study, Britz et al. (2007) have also observed an increase of alpha-tocopherol content in brown rice seeds after an increase in ambient temperature.

Mineral composition of the aerial parts was affected by fertilization treatments for most of the minerals evaluated in the present study (Table 7). Differences were also observed between harvests in the first growing period, but only for specific minerals and fertilization treatments. In particular, $\mathrm{K}$ content was higher in the first harvest and for fertilizer treatments F2-F5, whereas Mn and Fe content was higher in the second harvest for most of the treatments (Table 7). Moreover, K, $\mathrm{Mn}$ and $\mathrm{Zn}$ contents were higher in the first growing period, as well as
Fe content for treatments F1, F4 and F5, whereas Ca content was higher in the second growing period. According to Errebhi and Wilcox (1990), the response to nitrate: ammonium ratio of the nutrient solution depends on the species with significant differences in plant growth and nutrient uptake being reported. Moreover, Cai et al. (2016) have reported that fertilizer type may have a significant impact on minerals uptake by green leafy vegetables, especially under high temperatures that may accelerate nitrogen availability of slow release fertilizers. Although mineral composition of wild or cultivated ecotypes has been already reported (Petropoulos et al., 2016; Zeghichi et al., 2003), to our knowledge this is the first time that mineral composition of $C$. spinosum in relation to fertilization rates is reported.

Nitrate content was significantly affected by ammonium nitrogen rate, with treatment $\mathrm{F} 4$ resulting in higher content, especially in the 1st harvest of both growing seasons, but similar to treatment F3. According to Savvas et al. (2006), increasing ammonium nitrogen in nutrient solution does not increase nitrogen utilization from lettuce plants, while Demsar and Osvald (2003) have reported that increasing ammonium nitrogen up to $100 \%$ of total nitrogen resulted in a significant decrease of nitrates content in lettuce leaves. Therefore, considering the high amounts of nitrates in nutrient solution of treatments F3 and F4 (Table 1), the higher leaf nitrates content for these treatments (1st harvest of both growing seasons) could be explained by the higher availability and uptake of nitrates without however being associated with higher assimilation for biosynthetic purposes. Furthermore, the increase of ammonium nitrogen for the same treatments (F3 and F4) and harvests could not alleviate the negative effect of high nitrates uptake from plants, whereas in treatment F5 where the highest amount of ammonium nitrogen was applied, a significant decrease of nitrates was observed. Although temperatures were higher during the 2nd growing period, no significant differences between the growing seasons were observed, which probably indicates an efficient nitrate reductase activity for the applied nitrogen amounts and the climate conditions of this study. In contrast, De Pascale et al. (2009) reported that nitrates content in leaves of Brassica rapa var. sylvestris was lower during the spring growing period in comparison to winter growing period. This could be attributed to the increased nitrate reductase activity due to higher light intensity in the spring growing period.

In the 1st growing period, total nitrogen content in leaves was higher in plants of $\mathrm{H} 3$ treatment, as well as in 2nd growing period for all the fertilizer treatments, indicating a significant effect of temperature on nitrogen availability in nutrient solution and consequently in nitrogen uptake by plants (Table 7). Similar results have been reported by (Cai et al., 2016), who also observed differences in total nitrogen absorption by Brassica chinensis L. plants between different growing conditions and fertilizer types.

Antioxidant properties of $C$. spinosum leaves are of great importance in order to recommend its commercial cultivation as a healthy food. In this study, all the studied antioxidant properties assays (i.e. reducing power, DPPH, $\beta$-carotene scavenging activity, and TBARS inhibition) were affected by fertilization treatments and growth periods (Table 8). In particular, the lowest $\mathrm{EC}_{50}$ values (higher antioxidant activity) were recorded in the 2nd growing period, while differences were also observed between the harvests in the 1st growing period, where the lowest $\mathrm{EC}_{50}$ values were recorded for $\mathrm{H} 3$ treatment for almost all the tested assays and fertilizer treatments. Therefore, harvesting of leaves in mid to late spring, as is the case for plants of H3 treatment of the 1st growing period and plants of the 2nd growing period, may result in higher antioxidant activity. This could be attributed to differences in climate conditions during these growing periods (higher temperatures during early spring than winter), which could induce stress conditions and trigger the biosynthesis of antioxidant compounds (Fallovo et al., 2011). Chatzigianni et al. (2017) have also reported that antioxidant properties of $C$. spinosum leaves are affected by both production cycle (e.g. successive harvests) and genotype. Luna et al. (2013) and Sofo et al. (2016) have also suggested that antioxidant properties of lettuce 
Table 9

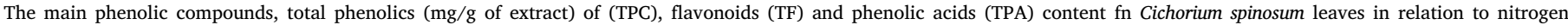
fertilization, number of harvests and growing period.

\begin{tabular}{|c|c|c|c|c|c|c|c|c|c|}
\hline \multirow[b]{2}{*}{ Harvest } & \multirow[b]{2}{*}{ Fertilization } & \multicolumn{5}{|c|}{ Main phenolic compounds (mg/g of extract) } & \multirow{2}{*}{$\begin{array}{l}\text { TPA } \\
\text { (mg/g of extract) }\end{array}$} & \multirow{2}{*}{$\begin{array}{l}\text { TF } \\
\text { (mg/g of extract) }\end{array}$} & \multirow{2}{*}{$\begin{array}{l}\text { TPC } \\
\text { (mg/g of extract) }\end{array}$} \\
\hline & & $1^{\mathrm{A}}$ & $3^{\mathrm{B}}$ & $4^{\mathrm{C}}$ & $5^{\mathrm{D}}$ & $8^{\mathrm{D}}$ & & & \\
\hline \multicolumn{10}{|c|}{ 1st Growing period } \\
\hline \multirow[t]{5}{*}{$\mathrm{H} 1$} & $\mathrm{~F} 1$ & 1.92 & 1.16 & 0.38 & 0.56 & 0.61 & $3.30^{\mathrm{eC}}$ & $2.18^{\mathrm{eC}}$ & $5.48^{\mathrm{eC}}$ \\
\hline & F2 & 2.77 & 1.76 & 0.45 & 0.77 & 0.77 & $4.78^{\mathrm{cC}}$ & $2.69^{\mathrm{cC}}$ & $7.47^{\mathrm{cC}}$ \\
\hline & F3 & 2.01 & 1.43 & 0.47 & 0.82 & 0.64 & $3.69^{\mathrm{dC}}$ & $2.57^{\mathrm{dC}}$ & $6.26^{\mathrm{dC}}$ \\
\hline & F4 & 3.28 & 4.01 & 0.79 & 1.27 & 1.07 & $7.50^{\mathrm{aC}}$ & $3.97^{\mathrm{aA}}$ & $11.47^{\mathrm{aC}}$ \\
\hline & F5 & 3.08 & 2.97 & 0.51 & 1.24 & 0.96 & $6.36^{\mathrm{bC}}$ & $3.51^{\mathrm{bA}}$ & $9.87^{\mathrm{bB}}$ \\
\hline \multirow[t]{5}{*}{$\mathrm{H} 2$} & $\mathrm{~F} 1$ & 2.91 & 2.60 & 0.39 & 1.10 & 0.57 & $5.95^{\mathrm{eB}}$ & $2.83^{\mathrm{eB}}$ & $8.78^{\mathrm{eB}}$ \\
\hline & $\mathrm{F} 2$ & 3.09 & 3.85 & 0.47 & 1.40 & 0.76 & $7.47^{\mathrm{cB}}$ & $3.50^{\mathrm{cB}}$ & $10.97^{\mathrm{cB}}$ \\
\hline & F3 & 4.16 & 6.54 & 0.73 & 1.57 & 1.14 & $11.09^{\mathrm{aB}}$ & $4.36^{\mathrm{aB}}$ & $15.44^{\mathrm{aB}}$ \\
\hline & F4 & 3.72 & 6.56 & 0.54 & 1.60 & 0.76 & $10.70^{\mathrm{bB}}$ & $3.68^{\mathrm{bB}}$ & $14.39^{\mathrm{bB}}$ \\
\hline & F5 & 2.80 & 3.45 & 0.39 & 1.28 & 0.67 & $6.64^{\mathrm{dB}}$ & $3.10^{\mathrm{dB}}$ & $9.74^{\mathrm{dB}}$ \\
\hline \multirow[t]{5}{*}{ H3 } & $\mathrm{F} 1$ & 4.22 & 8.83 & 0.64 & 1.75 & 0.86 & $13.50^{\mathrm{bA}}$ & $4.17^{\mathrm{cA}}$ & $17.66^{\mathrm{cA}}$ \\
\hline & $\mathrm{F} 2$ & 5.64 & 9.34 & 0.70 & 1.59 & 1.10 & $15.44^{\mathrm{aA}}$ & $4.32^{\mathrm{bA}}$ & $19.76^{\mathrm{aA}}$ \\
\hline & F3 & 6.84 & 6.60 & 0.81 & 1.96 & 1.35 & $13.77^{\mathrm{bA}}$ & $5.12^{\mathrm{aA}}$ & $18.89^{\mathrm{bA}}$ \\
\hline & F4 & 5.20 & 6.84 & 0.80 & 1.05 & 1.13 & $12.40^{\mathrm{cA}}$ & $3.78^{\mathrm{dB}}$ & $16.18^{\mathrm{dA}}$ \\
\hline & F5 & 3.93 & 5.05 & 0.56 & 1.52 & 0.62 & $9.17^{\mathrm{dA}}$ & $3.51^{\mathrm{eA}}$ & $12.68^{\mathrm{eA}}$ \\
\hline \multicolumn{10}{|c|}{ 2nd Growing period } \\
\hline \multirow[t]{5}{*}{$\mathrm{H} 1$} & $\mathrm{~F} 1$ & 11.10 & 25.44 & 4.01 & 3.94 & 3.52 & $37.02^{\mathrm{d} *}$ & $13.90^{\mathrm{b} *}$ & $50.93^{\mathrm{b} *}$ \\
\hline & $\mathrm{F} 2$ & 16.00 & 24.87 & 3.47 & 2.75 & 2.87 & $41.29^{\mathrm{bc} *}$ & $11.25^{\mathrm{c} *}$ & $52.54^{\mathrm{b} *}$ \\
\hline & F3 & 12.96 & 25.35 & 3.54 & 3.80 & 3.77 & $39.88^{c_{*}}$ & $13.95^{\mathrm{b} *}$ & $52.89^{\mathrm{b} *}$ \\
\hline & $\mathrm{F} 4$ & 17.72 & 38.89 & 5.34 & 2.62 & 4.81 & $59.63^{a *}$ & $16.25^{\mathrm{a} *}$ & $73.51^{\mathrm{a} *}$ \\
\hline & F5 & 15.06 & 27.41 & 2.66 & 1.79 & 2.26 & $42.98^{\mathrm{b} *}$ & $8.14^{d_{*}}$ & $51.12^{\mathrm{b} *}$ \\
\hline \multicolumn{2}{|c|}{ Standard error } & 1.14 & 2.48 & 0.34 & 0.21 & 0.28 & 3.71 & 0.97 & 4.55 \\
\hline
\end{tabular}

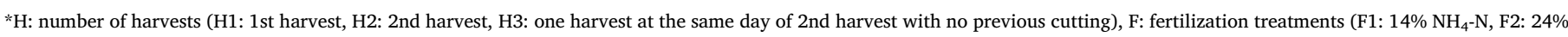
$\left.\mathrm{NH}_{4}-\mathrm{N}, \mathrm{F} 3: 34 \% \mathrm{NH}_{4}-\mathrm{N}, \mathrm{F} 4: 43 \% \mathrm{NH}_{4}-\mathrm{N}, \mathrm{F} 5: 53 \% \mathrm{NH}_{4}-\mathrm{N}\right)$.

$1^{\mathrm{A}}$ : 5-O-Caffeoylquinic acid; $3^{\mathrm{B}}$ : Chicoric acid; $4^{\mathrm{C}}$ : Quercetin-3-O-glucuronide; $5^{\mathrm{D}}$ : Kaempferol-O-glucuronide; $8^{\mathrm{D}}$ : Kaempferol-3-O-glucuronide.

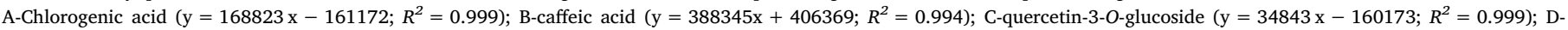
kaempferol-3-O-rutinoside (y $\left.=11117 \mathrm{x}+30861 ; R^{2}=0.999\right)$.

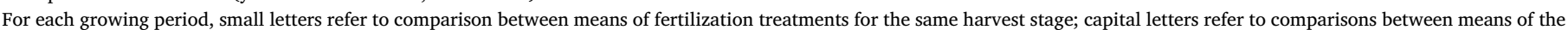

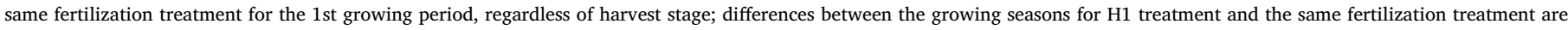
indicated by the use of $(*)$ symbol. Mean separation was made with Tukey HSD test at $\mathrm{p}<.05$.

may be affected by fertilization treatments and growing systems, while Fallovo et al. (2011) have suggested that apart from nutrient solution composition, growing season may also affect chemical composition of lettuce.

The detected phenolic compounds in $C$. spinosum leaves and have been previously reported by the authors (Petropoulos et al., 2017a, 2017b, 2017c). The same compounds have been identified in other cultivated Cichorium species (Carazzone et al., 2013; Ferioli et al., 2015). The most abundant phenolics were chicoric acid and 5-O-caffeoylquinic acid, followed by quercetin-3-O-glucuronide, kaempferol-Oglucuronide and kaempferol-3-O-glucuronide (Table 9). The highest content of total phenolics (TPC) was recorded in the 2nd growing period and for fertilizer treatment F4. Phenolic compounds content followed a similar trend with antioxidant properties (Table 8), with plants of the 2nd growing period having a higher content of phenolic compounds than the 1 st growing period. This may be attributed to higher solar radiation level, which was higher during the 2nd growing period (Fig. 1). Chatzigianni et al. (2017) have also reported a significant increase of total phenolic compounds content with increasing content of ammonium nitrogen in nutrient solution for a mountainous ecotype of C. spinosum, which implies the better adaptation of this ecotype under high solar radiation intensity, comparing to the ecotype adapted to sea level altitudes. This result could be further justified by a previous study of the authors (Petropoulos et al., 2016) where significant differences between various ecotypes of $C$. spinosum were reported in terms of nutritional value and chemical composition. Similarly, Becker et al. $(2014,2013)$ reported that the effect of radiation intensity on phenolic compounds composition of lettuce plants is compound dependent and apart from environmental factors, plant ontogeny is also important. In another study, Pérez-López et al. (2015) also observed that lettuce plants treated with high light intensities contained higher concentrations of carotenoids, glutathione, total phenols and anthocyanins, which was also the case in our study regarding total phenolic compounds content.

Moreover, the phenolic acids content was higher than that of flavonoids. The higher content of phenolic acids than flavonoids has been also confirmed in other Cichorium species, such as $C$. endivia and $C$. intybus, by Ferioli et al. (2015), while the authors (Petropoulos et al., 2017b) have reported a similar trend in C. spinosum plants grown under saline conditions. Considering the higher temperatures that prevailed during mid to late spring of the present study, plants were probably subjected to stress inducing conditions that could increase the biosynthesis of phenolic compounds (Fallovo et al., 2011), while Chatzigianni et al. (2017) have already reported the induction of phenolic compounds biosynthesis under high concentration of nutrient solution $\left(16 \mathrm{mmol} \mathrm{L}^{-1}\right)$ and high amounts of ammonium nitrogen $(50 \%$ of total nitrogen).

\section{Conclusions}

The availability of nitrogen in growth media throughout the growing season and the ammonium nitrogen content in nutrient solution have a significant effect on yield and quality of Cichorium spinosum leaves. Based on the present results, higher yields were obtained when both forms of $\mathrm{N}$ are supplied in equal amounts, $\mathrm{F} 4$, or when ammonium nitrogen prevails in the nutrient solution, F5, since plants regulate intracellular $\mathrm{pH}$ and are able to store $\mathrm{N}$ at lower energy costs. Moreover, the application of successive harvesting may increase the growing period of $C$. spinosum and therefore contribute to higher total yields. Besides the growing conditions (solar radiation and temperature), harvest stage had a significant effect on chemical composition and bioactive compounds content, especially during the 2nd growing 
period, where higher temperatures and solar radiation prevailed. In conclusion, nitrogen form should be considered together with growing period and harvest stage as useful means towards tailoring the quality of the final product. Although the present results indicate that ammonium nitrogen rates, up to $54 \%$ of total nitrogen, had no detrimental effects on total yield and quality of $C$. spinosum, it could be interesting to further investigate the effect of slow-release nitrogen fertilizers as well as of nitrate: ammonium nitrogen ratio in nutrient solution on plant development, chemical composition and quality of $C$. spinosum plants, in order to evaluate possible toxicity effects, as well antagonistic effects to other cationic nutrients.

\section{Acknowledgements}

The authors thank the Foundation for Science and Technology (FCT, Portugal) and FEDER under Programme PT2020 for financial support to CIMO (UID/AGR/00690/2013) and L. Barros (SFRH/BPD/107855/ 2015) grant. This work was also financially supported by: Project POCI01-0145-FEDER-006984-Associate Laboratory LSRE-LCM funded by FEDER through COMPETE2020-Programa Operacional Competitividade e Internacionalização (POCI)-and by national funds through FCT-Fundação para a Ciência e a Tecnologia.

\section{References}

Anesti, S., Fasoli, K., Petropoulos, S., Ntatsi, G., Antoniadis, V., Ferreira, I.C.F.R., 2016 Effect of ammonium fertilizer on growth and quality of Cichorium spinosum plants. VII International Scientific Agriculture Symposium Agrosym 2016, 827-833.

Becker, C., Kläring, H., Kroh, L.W., Krumbein, A., 2013. Temporary reduction of radiation does not permanently reduce $\mathrm{fl}$ avonoid glycosides and phenolic acids in red lettuce. Plant Physiol. Biochem. 72, 154-160. http://dx.doi.org/10.1016/j.plaphy.2013.05. 006.

Becker, C., Klaering, H., Schreiner, M., Kroh, L.W., Krumbein, A., 2014. Unlike quercetin glycosides, cyanidin glycoside in red leaf lettuce responds more sensitively to increasing low radiation intensity before than after head formation has started. J. Agric. Food Chem. 62, 6911-6917.

Bessada, S.M.F., Barreira, J.C.M., Barros, L., Ferreira, I.C.F.R., Oliveira, M.B.P.P., 2016 Phenolic profile and antioxidant activity of Coleostephus myconis (L.) Rchb.f.: An underexploited and highly disseminated species. Ind. Crops Prod. 89, 45-51. http:// dx.doi.org/10.1016/j.indcrop.2016.04.065.

Bloom, a J., Caldwell, R.M., Finazzo, J., Warner, R.L., Weissbart, J., 1989. Oxygen and carbon dioxide fluxes from barley shoots depend on nitrate assimilation. Plant Physiol. 91, 352-356. http://dx.doi.org/10.1104/pp.91.1.352.

Bonasia, A., Lazzizera, C., Elia, A., Conversa, G., 2017. Nutritional, biophysical and physiological characteristics of wild rocket genotypes as affected by soilless cultivation system, salinity level of nutrient solution and growing period. Front. Plant Sci. 8, 15. http://dx.doi.org/10.3389/fpls.2017.00300.

Bose, B., Srivasava, H., 2001. Absorption and accumulation of nitrate in plants: influence of environmental factors. Indian J. Exp. Bot. 39, 101-110.

Britto, D.T., Kronzucker, H.J., 2002. $\mathrm{NH}_{4}{ }^{+}$toxicity in higher plants: a critical review. J. Plant Physiol. 159, 567-584. http://dx.doi.org/10.1078/0176-1617-0774.

Britto, D., Kronzucker, H., 2013. Ecological significance and complexity of N-source preference in plants. Ann. Bot. 112, 957-963. http://dx.doi.org/10.1093/aob/ mct157.

Britz, S.J., Prasad, P.V., Moreau, R.A., Allen Jr., L.H., Kremer, D.F., Boote, K.J., 2007. Influence of growth temperature on the amounts of tocopherols, tocotrienols, and amma-oryzanol in brown rice. J. Agric. Food Chem. 55, 7559-7565. http://dx.doi. org/10.1021/jf0637729.

Cai, S., Zhu, H., Wang, J., Yu, T., Qian, X., Shan, Y., Tian, J., 2016. Fertilization impacts on green leafy vegetables supplied with slow release nitrogen fertilizers. J. Plant Nutr. 39, 1421-1430. http://dx.doi.org/10.1080/01904167.2015.1050508.

Carazzone, C., Mascherpa, D., Gazzani, G., Papetti, A., 2013. Identification of phenolic constituents in red chicory salads (Cichorium intybus) by high-performance liquid chromatography with diode array detection and electrospray ionisation tandem mass spectrometry. Food Chem. 138, 1062-1071. http://dx.doi.org/10.1016/j.foodchem. 2012.11.060.

Cataldo, D.A., Maroon, M., Schrader, L.E., Youngs, V.L., 1975. Rapid colorimetric determination of nitrate in plant tissue by nitration of salicylic acid. Commun. Soil Sci. Plant Anal. 6, 71-80. http://dx.doi.org/10.1080/00103627509366547.

Chatzigianni, M., Alkhaled, B., Livieratos, I., Stamatakis, A., Ntatsi, G., Savvas, D., 2017. Impact of nitrogen source and supply level on growth, yield and nutritional value of two contrasting ecotypes of Cichorium spinosum L. grown hydroponically. J. Sci. Food Agric. http://dx.doi.org/10.1002/jsfa.8636.

Cocetta, G., Casciani, D., Bulgari, R., Musante, F., Kolton, A., Rossi, M., Ferrante, A., 2017. Light Use Efficiency for Vegetables Production in Protected and Indoor Environments. http://dx.doi.org/10.1140/epjp/i2017-11298-x.

Conesa, E., Ninirola, D., Vicente, M.J., Ochoa, J., Banon, S., Fernandez, J.A., 2009. The influence of nitrate/ammonium ratio on yield quality and nitrate: oxalate and vitamin C content of baby leaf spinach and bladder campion plants grown in a floating system. Acta Hortic. 843, 137-144.

Csizinszky, A.A., 1999. Yield response of herbs to nitrogen and potassium in sand in multiple harvests. J. Herbs Spices Med. Plants 6, 11-22. http://dx.doi.org/10.1300/ J044v06n04.

Demsar, J., Osvald, J., 2003. Influence of NO3-: NH4 + ratio on growth and nitrate accumulation in lettuce (Lactuca saliva var. capitata L.) in an aeroponic system. Agrochimica 47, 112-121.

De Pascale, S., Orsini, F., Vallone, S., Barbieri, G., 2009. Crop season effects on yield and quality of hydroponically grown Brassica rapa var. sylvestris. Acta Hortic. 807 427-432.

Erice, G., Sanz-Sáez, A., Aranjuelo, I., Irigoyen, J.J., Aguirreolea, J., Avice, J.C., SánchezDíaz, M., 2011. Photosynthesis, $\mathrm{N}_{2}$ fixation and taproot reserves during the cutting regrowth cycle of alfalfa under elevated $\mathrm{CO}_{2}$ and temperature. J. Plant Physiol. 168, 2007-2014. http://dx.doi.org/10.1016/j.jplph.2011.07.007.

Errebhi, M., Wilcox, G.E., 1990. Plant species response to ammonium- nitrate concentration ratios. J. Plant Nutr. 13, 1017-1029. http://dx.doi.org/10.1080/ 01904169009364132.

Fallovo, C., Rouphael, Y., Rea, E., Battistelli, A., Colla, G., 2009. Nutrient solution concentration and growing season affect yield and quality of Lactuca sativa L. var. acephala in floating raft culture. J. Sci. Food Agric. 89, 1682-1689. http://dx.doi.org/10. 1002/jsfa.3641.

Fallovo, C., Schreiner, M., Schwarz, D., Colla, G., Krumbein, A., 2011. Phytochemical changes induced by different nitrogen supply forms and radiation levels in two leafy brassica species. J. Agric. Food Chem. 59, 4198-4207. http://dx.doi.org/10.1021/ jf1048904.

Ferioli, F., Manco, M.A., D'Antuono, L.F., 2015. Variation of sesquiterpene lactones and phenolics in chicory and endive germplasm. J. Food Compos. Anal. 39, 77-86. http:// dx.doi.org/10.1016/j.jfca.2014.11.014.

Fontana, E., Hoeberechts, J., Nicola, S., Cros, V., Palmegiano, G.B., Peiretti, P.G., 2006. Nitrogen concentration and nitrate ammonium ratio affect yield and change the oxalic acid concentration and fatty acid profile of purslane (Portulaca oleracea L.) grown in a soilless culture system. J. Sci. Food Agric. 86, 2417-2424. http://dx.doi. org/10.1002/jsfa.2633.

Fu, Y., Li, H., Yua, J., Liu, H., Cao, Z., Manukovsky, N.S., Liu, H., 2017. Interaction effects of light intensity and nitrogen concentration on growth, photosynthetic characteristics and quality of lettuce (Lactuca sativa L. Var. youmaicai). Sci. Hortic. (Amst.) 214, 51-57. http://dx.doi.org/10.1016/j.scienta.2016.11.020.

Gautier, H., Diakou-Verdin, V., Bénard, C., Reich, M., Buret, M., Bourgaud, F., Poëssel, J.L., Caris-Veyrat, C., Génard, M., 2008. How does tomato quality (sugar, acid, and nutritional quality) vary with ripening stage, temperature, and irradiance? J. Agric. Food Chem. 56, 1241-1250. http://dx.doi.org/10.1021/jf072196t.

Glass, A.D.M., Britto, D.T., Kaiser, B.N., Kinghorn, J.R., Kronzucker, J., Kumar, A., Okamoto, M., Rawat, S., Siddiqi, M.Y., Unkles, E., Vidmar, J.J., 2002. The regulation of nitrate and ammonium transport systems in plants. J. Exp. Bot. 53, 855-864.

Guimarães, R., Barros, L., Dueñas, M., Calhelha, R.C., Carvalho, A.M., Santos-Buelga, C., Queiroz, M.J.R.P., Ferreira, I.C.F.R., 2013. Nutrients, phytochemicals and bioactivity of wild Roman chamomile: a comparison between the herb and its preparations. Food Chem. 136, 718-725. http://dx.doi.org/10.1016/j.foodchem.2012.08.025.

Guo, S., Brück, H., Sattelmacher, B., 2002. Effects of supplied nitrogen form on growth and water uptake of French bean (Phaseolus vulgaris L.) plants. Nitrogen form and water uptake. Plant Soil 267-275.

Hord, N.G., Tang, Y., Bryan, N.S., 2009. Food sources of nitrates and nitrites: the physiologic context for potential health benefits. Am. J. Clin. Nutr. 90, 1-10. http://dx. doi.org/10.3945/ajen.2008.27131.

Hussain, N., Li, H., Jiang, Y., Jabeen, Z., Shamsi, I.H., Ali, E., Jiang, L., 2014. Response of seed tocopherols in oilseed rape to nitrogen fertilizer sources and application rates. J. Zhejiang Univ. Sci. B 15, 181-193. http://dx.doi.org/10.1631/jzus.B1300036.

Islam, M.S., Khan, S., 2001. Seasonal fluctuations of carbohydrate accumulation and metabolism of three tomato (Lycopersicum esculentum Mill.) cultivars grown at seven sowing times. J. Hortic. Sci. Biotechnol. 76, 764-770.

Kim, D.J., Lee, D.I., Keller, J., 2006. Effect of temperature and free ammonia on nitrification and nitrite accumulation in landfill leachate and analysis of its nitrifying bacterial community by FISH. Bioresour. Technol. 97, 459-468. http://dx.doi.org/ 10.1016/j.biortech.2005.03.032.

Kmiecik, W., Lisiewska, Z., 1999. Comparison of leaf yields and chemical composition of Hamburg and leafy types of parsley. Folia Hortic. 11, 53-63.

Libert, B., Franceschi, V.R., 1987. Oxalate in crop plants. J. Agric. Food Chem. 35, 926-938.

Liu, X., Lu, L., Chen, Q., Ding, W., Dai, P., Hu, Y., Yu, Y., Jin, C., Lin, X., 2015. Ammonium reduces oxalate accumulation in different spinach (Spinacia oleracea L.) genotypes by inhibiting root uptake of nitrate. Food Chem. 186, 312-318. http://dx.doi.org/10. 1016/j.foodchem.2014.06.122.

Lombardo, S., Restuccia, C., Muratore, G., Barbagallo, R.N., Licciardello, F., Pandino, G., Scifò, O., Mazzaglia, A., Ragonese, F., Mauromicale, G., 2016. Effect of nitrogen fertilization on the overall quality of minimally processed globe artichoke heads. J. Sci. Food Agric. http://dx.doi.org/10.1002/jsfa.7784.

Luna, M.C., Martínez-Sánchez, A., Selma, M.V., Tudela, J.A., Baixauli, C., Gil, M.I., 2013. Influence of nutrient solutions in an open-field soilless system on the quality characteristics and shelf life of fresh-cut red and green lettuces (Lactuca sativa L.) in different seasons. J. Sci. Food Agric. 93, 415-421. http://dx.doi.org/10.1002/jsfa. 5777 .

Marschner, H., 1995. Mineral Nutrition of Higher Plants, 2nd ed. Academic Press, New York.

Melliou, E., Magiatis, P., Skaltsounis, A.L., 2003. Alkylresorcinol derivatives and sesquiterpene lactones from Cichorium spinosum. J. Agric. Food Chem. 51, 1289-1292. 
http://dx.doi.org/10.1021/jf025848g.

O’Bryan, C.A., Crandall, P., Jaroni, P., Ricke, S.C., Gibson, K.E., 2017. Assessment of nitrogen and phosphorus loads present in environments impacted by alternative poultry processing operations utilized in pasture-raised poultry production. Renew. Agric. Food Syst. 32, 33-42.

Pérez-López, U., Miranda-Apodaca, J., Muñoz-Rueda, A., Mena-Petite, A., 2015. Interacting effects of high light and elevated $\mathrm{CO}_{2}$ on the nutraceutical quality of two differently pigmented Lactuca sativa cultivars (Blonde of Paris Batavia and Oak Leaf). Sci. Hortic. (Amst.) 191, 38-48. http://dx.doi.org/10.1016/j.scienta.2015.04.030.

Palaniswamy, U.R., McAvoy, R.J., Bible, B., 2004. Oxalic acid concentrations in purslane (Portulaca oleraceae L.) is altered by the stage of harvest and the nitrate to ammonium ratios in hydroponics. Sci. Hortic. (Amsterdam) 629, 299-305. http://dx.doi.org/10. 1016/j.scienta.2004.01.006

Pereira, C., Barros, L., Carvalho, A.M., Ferreira, I.C.F.R., 2013. Use of UFLC-PDA for the analysis of organic acids in thirty-five species of food and medicinal plants. Food Anal. Methods 6, 1337-1344. http://dx.doi.org/10.1007/s12161-012-9548-6.

Petropoulos, S.A., Fernandes, Â., Barros, L., Ferreira, I.C.F.R., Ntatsi, G., 2015 Morphological, nutritional and chemical description of Vatikiotiko, an onion local landrace from Greece. Food Chem. 182, 156-163. http://dx.doi.org/10.1016/j. foodchem.2015.03.002.

Petropoulos, S.A., Ntatsi, G., Levizou, E., Barros, L., Ferreira, I.C.F.R., 2016. Nutritional profile and chemical composition of Cichorium spinosum ecotypes. LWT - Food Sci. Technol. 73, 95-101. http://dx.doi.org/10.1016/j.lwt.2016.05.046.

Petropoulos, S.A., Levizou, E., Ntatsi, G., Fernandes, Â., Petrotos, K., Akoumianakis, K., Barros, L., Ferreira, I.C.F.R., 2017a. Salinity effect on nutritional value, chemical composition and bioactive compounds content of Cichorium spinosum L. Food Chem. 214, 129-136. http://dx.doi.org/10.1016/j.foodchem.2016.07.080.

Petropoulos, S., Fernandes, Â., Karkanis, A., Ntatsi, G., Barros, L., Ferreira, I.C.F.R., 2017b. Successive harvesting affects yield, chemical composition and antioxidant activity of Cichorium spinosum L. Food Chem. 237, 83-90. http://dx.doi.org/10.1016/ j.foodchem.2017.05.092.

Petropoulos, S.A., Fernandes, Â., Vasileios, A., Ntatsi, G., Barros, L., Ferreira, I.C.F.R., 2018c. Chemical composition and antioxidant activity of Cichorium spinosum L. leaves in relation to developmental stage. Food Chem. 239. http://dx.doi.org/10.1016/j. foodchem.2017.07.043.

Rosales, M.A., Cervilla, L.M., Sánchez-Rodríguez, E., Rubio-Wilhelmi, M., del, M., Blasco,
B., Ríos, J.J., Soriano, T., Castilla, N., Romero, L., Ruiz, J.M., 2011. The effect of environmental conditions on nutritional quality of cherry tomato fruits: evaluation of two experimental Mediterranean greenhouses. J. Sci. Food Agric. 91, 152-162. http://dx.doi.org/10.1002/jsfa.4166.

Savvas, D., Passam, H.C., Olympios, C., Nasi, E., Moustaka, E., Mantzos, N., Barouchas, P., 2006. Effects of ammonium nitrogen on lettuce grown on pumice in a closed hydroponic system. HortScience 41, 1667-1673.

Scheible, W.R., 1997. Nitrate acts as a signal to induce organic acid metabolism and repress starch metabolism in tobacco. Plant Cell 9, 783-798. http://dx.doi.org/10. 1105/tpc.9.5.783.

Sofo, A., Lundegårdh, B., Mårtensson, A., Manfra, M., Pepe, G., Sommella, E., De Nisco, M., Tenore, G.C., Campiglia, P., Scopa, A., 2016. Different agronomic and fertilization systems affect polyphenolic profile, antioxidant capacity and mineral composition of lettuce. Sci. Hortic. (Amst.) 204, 106-115. http://dx.doi.org/10.1016/j. scienta.2016.04.003.

Stagnari, F., Galieni, A., Pisante, M., 2015. Shading and nitrogen management affect quality, safety and yield of greenhouse-grown leaf lettuce. Sci. Hortic. (Amst.) 192, 70-79. http://dx.doi.org/10.1016/j.scienta.2015.05.003.

Szalai, G., Dai, N., Danin, A., Dudai, N., Barazani, O., 2010. Effect of nitrogen source in the fertilizing solution on nutritional quality of three members of the Portulaca oleracea aggregate. J. Sci. Food Agric. 90, 2039-2045. http://dx.doi.org/10.1002/ jsfa.4049.

Wang, S.Y., Camp, M.J., 2000. Temperatures after bloom affect plant growth and fruit quality of strawberry. Sci. Hortic. (Amst.) 85, 183-199. http://dx.doi.org/10.1016/ S0304-4238(99)00143-0.

Wang, J., Zhou, Y., Dong, C., Shen, Q., Putheti, R., 2009. Effects of NH4+ N/NO3-N ratios on growth, nitrate uptake and organic acid levels of spinach (Spinacia oleracea L.). Afr. J. Biotechnol. 8, 3597-3602 (CNKI:SUN:ZWYF. 0. 2007-04-019).

Zeghichi, S., Kallithraka, S., Simopoulos, A.P., 2003. Nutritional composition of molokhia (Corchorus olitorius) and stamnagathi (Cichorium spinosum). World Rev. Nutr. Diet. 91, $1-21$.

Zhang, Y.P.S.Y., Lin, X.Y., Zhang, Y.P.S.Y., Zheng, S.J., Du, S.T., 2005. Effects of nitrogen levels and nitrate/ammonium ratios on oxalate concentrations of different forms in edible parts of spinach. J. Plant Nutr. 28, 2011-2025. http://dx.doi.org/10.1080/ 01904160500311086. 